Annual Report

$$
\text { June } 1992
$$

Work Performed Under Contract No. DE-FC07-881012906

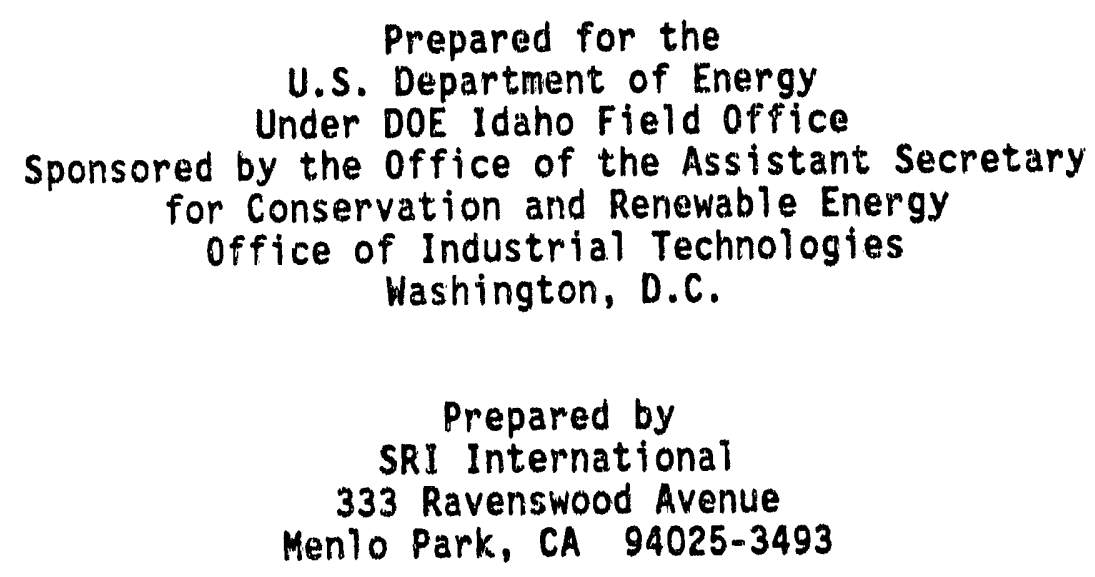




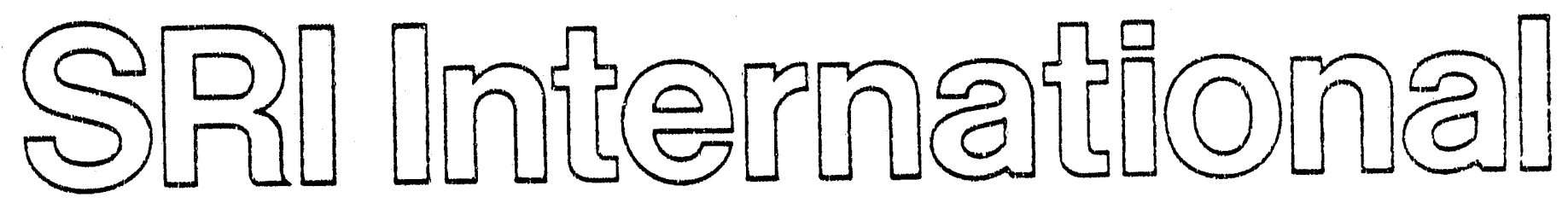

\section{RESEARCH AND DEVELOPMENT TO OVERCOME FOULING OF MEMBRANES}

Subhash C. Narang, Suniti K. Sharma, and Susanna C. Ventura

Polymer Chemistry and Technology

Chemistry Laboratory

and

Daryl L. Roberts and Nancy Ahner

Chemical Engineering Laboratory

SRI Project PYU-8330

Covering Period October 1, 1989 to October 31, 1990

Prepared for:

EG\&G Idaho

1955 Fremont St.

E-3, MS 3527

idaho Falls, ID 83415

Attn: Mr. Thomas W. Lawtord

Contract No. DE-FC07-891D12906

Approved:

David M. Golden

Chemistry Laboratory

G. R. Abrahamson

Senior Vice President

Sciences Group 


\section{SUMMARY}

During this first year of the program, we have successfully accomplished the main objective of demonstrating the feasibility of using piezoelectrically assisted ultrafiltration to reduce membrane fouling and enhance the flux through ultrafiltration membranes. A preliminary economic evaluation, accounting for the power consumption of the piezoelectric driver and the extent of permeate flow rate enhancement, has also shown that piezoelectrically assisted ultrafiltration is cost effective and economically competitive in comparison with traditional separation processes.

Piezoelectric transducers, such as a piezoelectric lead zirconate titanate (PZT) disc or a piezoelectric horn, driven by moderate power, significantly enhance the permeate flux on fouled membranes, presumably because they promote local turbulence. Several experiments were conducted on polysulfone and regenerated cellulose UF membranes fouled during filtration of model feed solutions. Solutions of poly (ethylene glycol) and of high-molecular weight dextran were used as models. We found that we could significantly increase the permeate flux by periodically driving the piezoelectric transducer, horn, or PZT disc, by application of moderate power over short periods of time, from 20 to 90 seconds. Enhancements as high as a factor of 8 were recorded within a few seconds, and enhanced permeate fluxes were maintained over a prolonged period (up to 3 hours). The prolonged flux enhancement makes it feasible to drive the piezoelectric transducer intermittently, thereby reducing the power consumption of the piezoelectric driver.

As piezoelectric drivers of sonically assisted ultrafiltration, PZT disc transducers are preferred over the piezoelectric hom because of their small size and ease of adaptability to ultrafiltration test cells. The horn transmits sonic energy to the UF membrane through a titanium element driven by a separate piezoelectric transducer, but a piezoelectric ceramic disc transmits energy directly to the UF membrane. Moreover, because piezoelectric ceramic elements can be fabricated in several configurations, they are potentially feasible for piezoelectrically driven ultrafiltration spiral-wound membrane modules.

Piezoelectrically assisted ultrafiltration by means of conventional UF membranes backed with piezoelectric polyvinylidene fluoride (PVDF) films showed the poor properties of PVDF films 
as piezoelectric drivers. Even when high voltage pulses were applied to polymorph PVDF membranes, no significant permeate flux enhancement was recorded.

Detailed feasibility studies were conducted to measure the long-term effect of a piezoelectric horn on ultrafiltration. Flux was enhanced by a factor of 4 for the filtration of a $1.0 \%$ polyethylene glycol solution through a regenerated cellulose UF membrane when a nominal power of 10 watts was applied to the piezoelectric horn in contact with a $47-\mathrm{mm}$ membrane. This specific experiment was run over 21 days, after having reached constant fouling of the membranz.

Even higher permeate flux enhancements were obtained with piezoelectric PZT disc drivers. Permeate flow rate was increased by a factor of 8 during the filtration of a $0.45 \%$ dextran solution through a UF polysulfone membrane ( $47 \mathrm{~mm}$ diameter) assisted i " a 2.5 -mm-thick lead zirconate titanate piezoelectric dise driven at 40 watts $\left(2.3 \mathrm{~W} / \mathrm{cm}^{2}\right)$. We ha not yet attempted to optimize the power consumption and performance of the piezoelectric PZT disc driver. PZT disc experiments have been repeated many times over a period of one month with consistent enhancement of the flux. No cross flow velocity experiments have been carried out in detail. However, the feed flow rate was maintained between 1.4 and $1.6 \mathrm{~L} / \mathrm{min}$.

Our experiments show that the PZT disc produces higher flux enhancements (up to a factor of 8) than the piezoelectric hom (up to a factor of 4). We believe that the PZT disc is a more efficient driver since it is free floating on the permeate side of the ultrafiltration membrane, while the piezoelectric hom that is adapted to constitute the top portion of the test cell is immobilized and therefore does not efficiently transmit energy to the membrane.

Because of the high efficiency and ease of adaptability of ceramic element drivers, we plan a detailed study of their long-term performance on piezoelectric-driven ultrafiltration in Year 2. This study will provide a basis for applying piezoelectrically assisted ultrafiltration to industrial processes such as whey protein filtration and solvent recovery in deasphalting. We will also pursue the development of ceramic piezoelectric drivers with controlled porosity to overcome the major limitarion of the PZT disc drivers and still provide a backing support to the ultrafiltration membrane. Further, we will configure one or more backing supports prototypical of the supports necessary for winding into spiral modules. 


\section{CONTENTS}

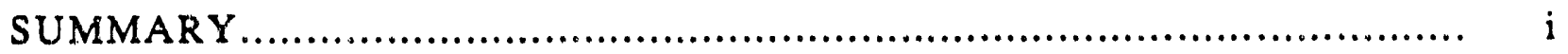

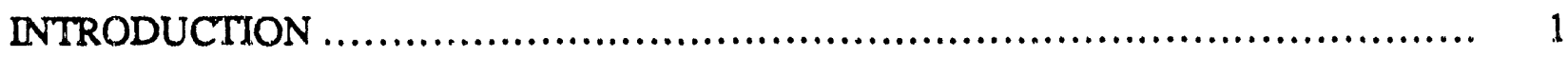

RESULTS AND DISCUSSION ..................................................... 3

Cross-Flow Ultrafiltration Test Apparatus ................................................ 4

Lead Zirconate Titanate (PZT) Piezoelectric Disc Assisted Ultrafiltration ...................... 6

Piezoelectric Ultrasonic-Horn-Assisted Ultrafiltration...................................... 13

PVDF-Film-Assisted Ultrafiltration.................................................. 22

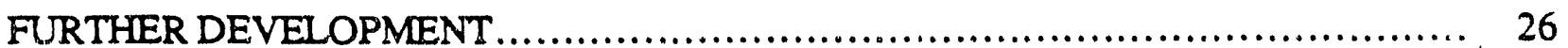

APPENDIX -- ECONOMIC EVALUATION OF SOLVENT RECOVERY IN

DEASPHAL TING OPERATIONS WITH PIEZOELECTRICALL Y ENHANCED

ULTRAFIL TRATION MEMBRANES 


\section{INTRODUCTION}

This study on "Research and Development to Overcome Fouling of Membranes" is the joint development of SRI's Department of Polymer Chemistry and Technology and its Membrane Separation Program. Our main objective is to develop innovative low-cost technological solutions to minimize fouling of membranes during ultrafiltration based on piezoelectric effects.

Ultrafiltration (UF) is being increasingly applied as a separation process in liquid industrial waste treatment, in food processing, and in the pharmaceutical and medical industries. However, commercial acceptance of ultrafiltration has been severely limited because membranes do not perform consistently for extended periods. Fouling of UF membranes results in a serious flux decline of the permeate and increases the cost of using a membrane separation process as a unit operation.

Ultrafiltration (UF) is being increasingly applied as a separation process in liquid industrial waste treatment, in food processing, and in the pharmaceutical and medical industries. Ultrafiltration applied to industrial processes, such as whey protein filtration and solvent recovery in deasphalting would be energy-saving, effective, and economically competitive with traditional separation processes if the membrane performances could be improved. Indeed, commercial acceptance of ultrafiltration has been severely limited because membranes do not perform consistently for extended periods. Fouling of UF membranes results in a serious flux decline of the permeate and increases the cost of using a membrane separation process as a unit operation.

UF membranes are vulnerable to fouling by pore blockage because they are hydrophobic and because they have low surface porosity and uneven pore sizes. Fouling generally proceeds as follows:

- The flux declines rapidly due to the buildup of solutes near the membrane surface.

- Macromolecules such as proteins are adsorbed on the hydrophobic membrane material and plug the pores.

- Particles deposited by convection and cake solids are compressed. 
The rate of decrease of the flux of the permeate through the membrane depends significantly on the particular composition of the liquid treated and on the interaction between solute and the membrane.

Several approaches have been tried to reduce fouling of membranes. Pretreatment of the membrane with hydrophilic surfactants and polymers to increase the initial flux and reduce the flux decline gives only a marginal and short-term improvement. Prefiltration of the feed solution with membranes of larger pore size adds the cost of another unit operation. Backwashing unplugs the blocked pores and dislodges the cake; however, it implies interruption of operation and can decrease membrane life.

To overcome fouling of membranes, SRI International is develcping unique piezoelectric backing for ultrafiltration membranes capable of producing local turbulence next to the membrane to minimize concentration polarization and the rate of buildup of solutes and particulate matter on the membrane surface. 


\section{RESULTS AND DISCUSSION}

To demonstrate the feasibility of using piezoelectrically assisted ultrafiltration to reduce fouling, we undertock three approaches. We used thin ceramic piezoelectric discs, a piezoelectric ultrasonic hom, and PVDF membranes as drivers to transmit energy to commercially available UF membranes. The effectiveness of the driver in producing local turbulence next to a fouled UF membrane was evaluated by monitoring the permeate flux enhancement.

We used regenerated cellulose with a molecular weight cut off (MWCO) of 10,000 and polysulfone with a MWCO of 100,000 as ultrafiltration membranes. We tested aqueous solutions of polyethylene glycol with molecular weight of 10,000, a derivative of polyethylene glycol with molecular weight of $15,000-20,000$, and dextran with molecular weight of 162,000 . Before testing the effect of the piezoelectric driver on ultrafiltration, we allowed the UF membranes to foul to an approximately constant permeate flux. The piezoelectric driver was applied on the permeate side. The metallized PVDF films and ceramic transducer were carefully encapsulated by an insulating polymer coating to ensure proper electrical insulation. For this purpose we used room temperature vulcanized (RTV) rubber, polyvinylchloride (PVC), and epoxy polymers.

We found that PZT discs have significant advantages over PVDF membranes or the piezoelectric ultrasonic hom. Piezoelectric PVDF films perform poorly in reducing fouling, most likely because of their insufficient electromechanical conversion. Indeed, the piezoelectric strain constants $\left(d_{i j}\right)$ of PVDF $\left(d_{31}=0.5 \times 10^{-12} \mathrm{C} / \mathrm{N}\right.$ and $\left.d_{33}=-7.5 \times 10^{-12} \mathrm{C} / \mathrm{N}\right)$ are quite low in comparison with other piezoelectric materiais ( $\mathrm{C} / \mathrm{N}$ means coulombs per newton). The piezoelectric strain constants are defined as follows:

$$
\mathrm{S}_{\mathrm{i}}=\mathrm{d}_{\mathrm{ji}} \mathrm{E}_{\mathrm{j}}
$$

where $S_{i}$ is a strain component, and $E_{j}$ is the applied electric field; the subscripts $i$ and $j$ refer to orthogonal directions, length and thickness, respectively, within the specimen. Since large $d_{i j}$ coefficient are desirable in piezoelectric driver applications, ceramic transciucers, such as PZT, appear best suited for ultrasonically assisted ultrafiltration (PZT has $\mathrm{d}_{31}=-93.5 \times 10-12 \mathrm{C} / \mathrm{N}$ and $d_{33}=223.0 \times 10^{-12} \mathrm{C} / \mathrm{N}$ ).

A PZT disc transducer is potentially more practical than the piezoelectric ultrasonic hom. The ultrasonic hom is a bulky piezoelectric driver that must be fastened to the ultrafiltration test 
cell, but a PZT disc can easily fit in a conventional cross-flow ultrafiltration flow cell with minimal modifications. PZT discs as thin as $2.5 \mathrm{~mm}$ produced significant flux enhancements. More important, thin piezoelectric discs are potentially feasible in commercial spiral-wound membran modules.

A cross-flow ultrafiluration test apparans was designed and assembled exclusively for this project, as described below.

\section{CROSS-FLOW ULTRAFILTRATION TEST APPARATUS}

A cross-flow ultrafiltration test apparatus was assembled for long-term evaluation of the membrane fouling. The apparatus is designed to circulate feed solution through two test cells that holi ultrafiltration membranes (Figure 1). This configuration allows the accurate and simultaneous evaluation of UF membranes driven and not-driven by a piezoelectric transducer, under the same operating conditions. The feed pump is a centrifugal five-stage pump with a maximum flow rate of 4 gallons per minute and a maximum pressure of $125 \mathrm{psig}$. The pressure in the system is adjusted through a back-pressure regulator. Our standard operating conditions are a pressure of 50 psig with a feed flow rate of about $1 / 2$ gallon per minute. The feed stream is split so that the piezoelectric and non-piezoelectric cells can be tested side by side. The non piezoelectric-driven cell is identical to the piezoelectric-driven cell in all respects except that it does not have any power supplied to the piezoelectric driver. The residue streams from each of the cells is recombined before passing through a throttle valve. The throttle valve has the function to maintain the pressure in the system. Because equal lengths of tubing have been used to supply the feed to both cells, the feed strearns to each cell are approximately similar. We measure the permeate flux through each membrane. Any difference in flux directly measures the effect of the piezoelectric vibration on the fouling of the UF merrabrane. Both the permeate stream and the combined residue stream can be sampled for analysis. To maintain constant feed conditions, the test apparatus is designed with total recycle. A copper coil with cooling water is inserted into the feed tank to maintain constant temperature in the system. The temperature of the feed is monitored with a tivermocouple.

Commercial UF membranes with 10,000 and 100,000 molecular weight cut-off (MNCO) were used in this study. We studied polysulfone membranes mounted on a polypropylene suppor (Millipore type PTGC) and low-protein binding regenerated cellulose membranes bound to a polypropylene suppor (Millipore type PLGC). Stainless steel support filters with ten and twenty micron pores were used to provide structural support to the UF membranes, if required. 


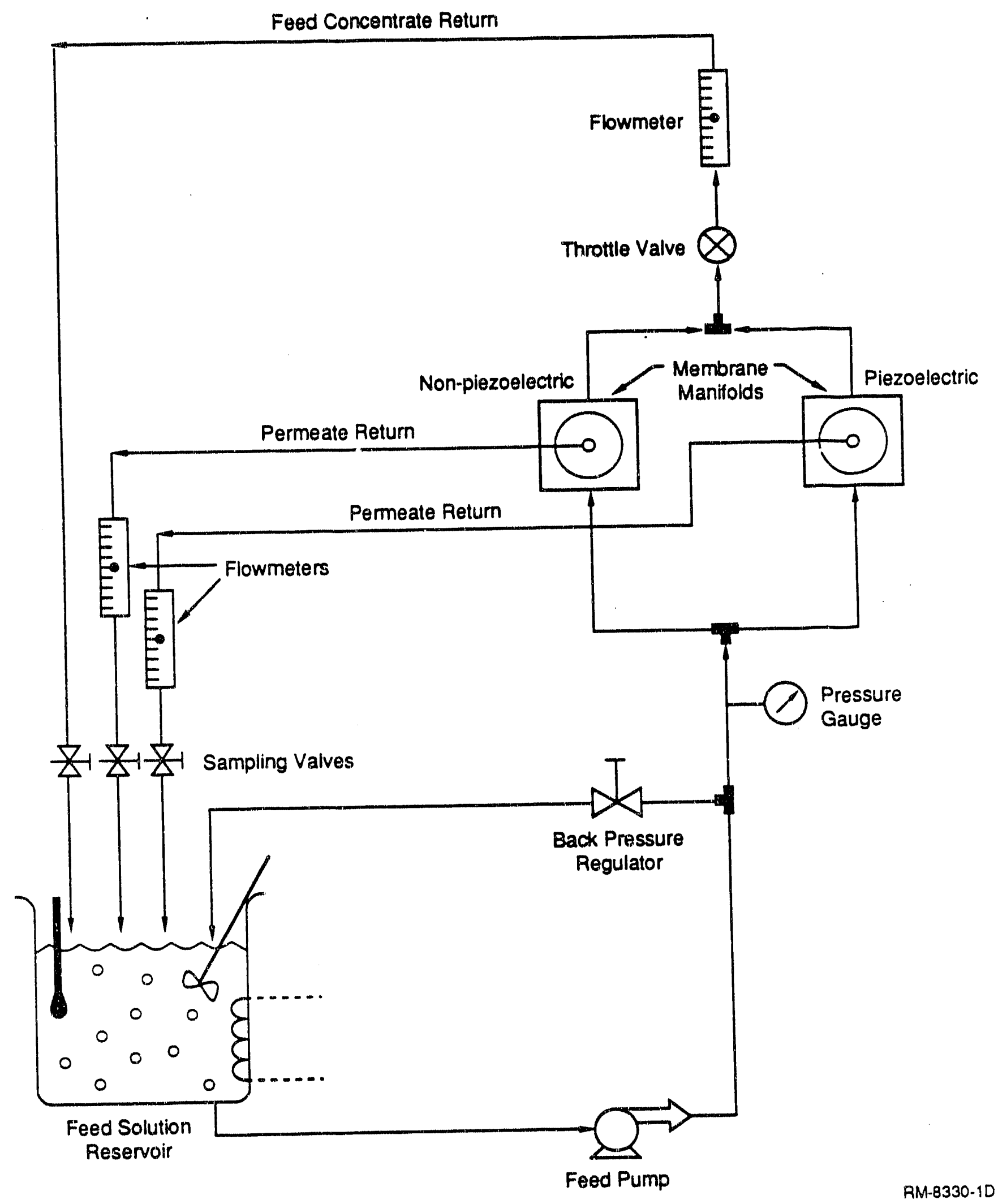

Figure 1. Cross-flow ulirafiltration test apparatus. 
As a standard procedure, between different runs, the system is thoroughly cleaned to prevent contamination. A $2 \%$ solution of citric acid is run for one hour to remove traces of metal from the system. Deionized water is then run for fifteen minutes for rinsing the system. A $0.2 \%$ Micro detergent solution is run for one hour to remove proteins and amino acids. Several more deionized rinses follow. Care was taken to run the final two rinses with Milli-Q (18 megaohm) water. The entire cleaning procedure is always carried out with no membrane so as to ensure a thorough cleaning of both sides of the system.

\section{LEAD ZIRCONATE TITANATE (PZT) PIEZOELECTRIC DISC ASSISTED ULTRAFILTRATION}

Piezoeloctrically assisted ultrafiltration by means of a piezoelectric lead zirconate titanate disc is an entirely new approach to reduce fouling. By application of moderate voltages to a PZT disc on the permeate side of the UF membrane, a significant enhancement of permeate flow rate is monitored. We believe that the PZT driver produces local turbulence next to the UF membrane to minimize concentration polarization and the rate of build up of solutes and particulate matter on the membrane surface.

Ring and disc-shaped PZT transducers were tested to transmit sonic power to UF membranes. The transducers were placed on the permeate side of the UF membrane, where they are not subjected to high pressure. Disc-shaped PZT transducers provided the best performances. Electrical wires were connected to a metallized PZT disc of $38 \mathrm{~mm}$. diameter and of $2.5 \mathrm{~mm}$ thickness. The disc and the electrical leads were electrically insulated by encapsulation with a fluoroepoxy coating. The schematic representation of the PZT disc driven ultrafiltration test cell is illustrated in Figure 2. The PZT disc is not in direct contact with the UF membrane, but "floats" on the permeate side. By application of a moderate power, such as 40 watts, mechanical strain is produced along orthogonal directions. Limensional changes of thickness, length or width, depending on the resonance frequency, are responsible for the generation of local turbulence on the permeate side, which is transmitted to the UF membrane.

It is highly desirable to operate the piezoelectric element at one of the resonance frequencies, since under these conditions the resistance of the element is minimal, thus allowing a high degree of power conversion into vibrational energy. For the disc shaped PZT transducer, fundamental resonance frequencies $\left(V_{r}\right)$ of the radial and thickness mode can be calculated as follows: 


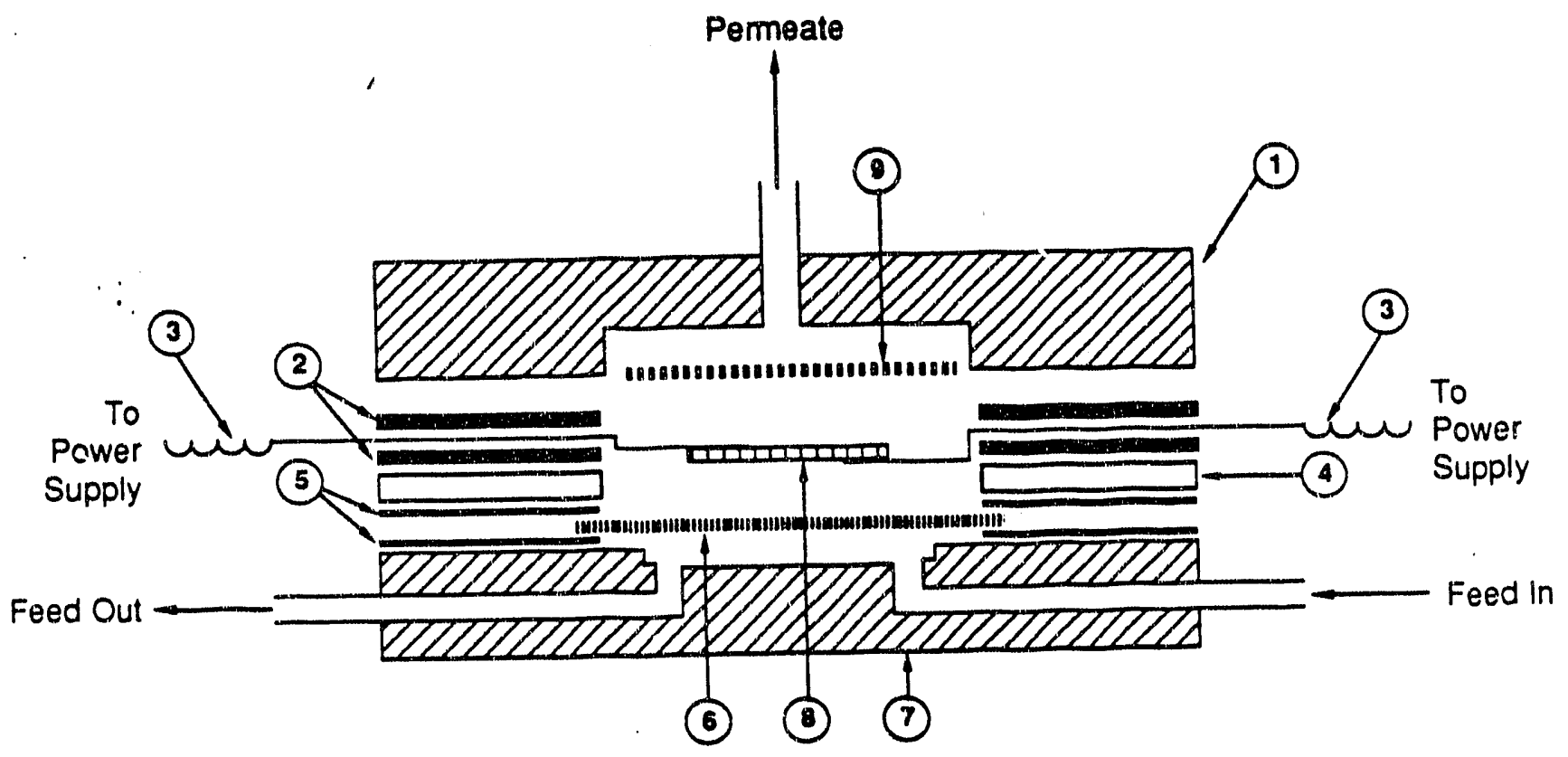

1. Top half

6. Ultrafiltration membrane

2. Thick rubber gaskets

7. Bottom hali

3. Electrical leads

8. PZT disc transducer

4. LEXAN ring

9. Microtitter

5. Thin rubber gaskets

Figure 2. PZT disc-driven uttrafiltration tesi cell. 


$$
v_{r}=\frac{V}{2 t}
$$

where $V_{r}$ is the resonance frequency; $V$ is the velocity of sound in the PZT disc; and $t$ is the measurement of the disc dimension through which the strain deformation takes place. In our calculations, we have used a value of $4000 \mathrm{~ms}^{-1}$ for the velocity of the sound in PZT. This value represents an average of the values reported for different PZT formulations. It should be also notes that the physical description of the transducer by this equation is a simplification that does not take in account that the PZTI disc is held by two metal strips and is coated by a polymer film.

We have calculated a $52 \mathrm{KHz}$ symmetric radial resonance frequency for a PZT disc of 38 $\mathrm{mm}$. of diameter while, the symmetric thickness frequency is at about $800 \mathrm{KHz}$ for a disc thickness of $2.5 \mathrm{~mm}$.. Both these values are in reasonable agreernent with the resonance is wuencies of 47 $\mathrm{KHz}$ and $750 \mathrm{KFiz}$ obseived from experimental measurement of the impedance as a function of frequency.

PZT disc assisted ultrafiltration tests were run by operating the piezoelectric transducer at $47 \mathrm{KHz}$, that represents the radial resonance mode of vibration of the disc. A simplified representation of the symmetric vibration mode is shown as follows. This radial resonance leads to buckling of the disc resulting in a displacement perpendicular to the disc.
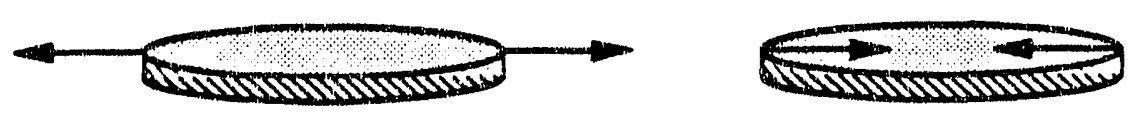

We believe that under the operating conditions this radial deformation is responsible for the local turbulence next to the membrane, expected to reduce fouling and enhance the permeate flux through the UF rembrane.

The feasibility of PZT disc-driven ultrafiltration was tested in the following experiments. A $0.45 \%$ solution of dextran $\left(\mathrm{M}_{w} 162,000\right.$ daltons) in water was filtered through a Millipore 
polysulfone UF membrane with a nominal MWCO of 100,000 . The insulated PZT disc was inserted in the ultrafiltration test apparatus. The feed solution was filtered at $50 \mathrm{psig}$ under crossflow conditions for a few days to reach steady fouling conditions. The permeate flux was 0.34 $\mathrm{mL} / \mathrm{min}$. Forty watts of power was applied to the PZT transducer for 90 seconds by means of the power supply shown in Figure 3. The permeate flow rate increased to $2.78 \mathrm{~mL} / \mathrm{min}$. We turned off the power, and after more than one hour and half the permeate flux was still higher than the permeate flux before power was applied. The permeate flux changes are shown in Figure 4. Under these conditions, piezoelectric vibration increased the permeate flux as much as by a factor of 8 .

In a similar test, we filtered a $0.58 \%$ dextran solution with a Millipore UF membrane with nominal MWCO of 100,000 . At 50 psig a steady fouling condition was reached with a permeate flux of $0.30 \mathrm{~mL} / \mathrm{min}$. Forty watts of power was applied to the PZT ransducer for 90 seconds, and the permeate flux increased to $2.1 \mathrm{~mL} / \mathrm{min}$ (a factor of 7). Permeate volumes were collected at constant intervals of time, and the cumulative volumes were plotted versus time (Figure 5). The effect of only 90 seconds of piezoelectric vibration is quite evident on the trend of the permeate volume collected. It took 3 hours for the system to return to the original permeate flux of 0.30 $\mathrm{mL} / \mathrm{min}$. It should be noted that no attempt has yet been made to optimize power consumption and performance of the piezoelectric ceramic disc driver.

The configuration of the PZT transducer is an important parameter, as shown by some experiments we did with a PZT ring-shaped transducer instead of the PZT disc. The ring had an intemal diameter of $3 / 4$ inch and an extemal diameter of 1 inch, and a thickness of $1 / 2$ inch. The ring was metallized on the inner and outer surfaces and poled radially. We attached electrical leads to the two metallized surfaces and the ring was completely coated with a thin layer, of epoxy for electrical insulation. In air the PZT ring showed a minimum impedance at $40.394 \mathrm{KHz}$, corresponding to the radial resonance mode of vibration of the ring. At this frequency, in-phase dimensional changes of the inner and outer ring diameter take place. However, when immersed in water, this radial mode of displacement was severely attenuated, as shown by experimental measurements of impedance as a function of frequency. Nevertheless, a PZT ring-assisted ultrafiltration test was carried out by resonating the PZT ring in the frequency range of approximately $30 \pm 10 \mathrm{KHz}$. The voltage applied to the ring was amplified by means of a amplifier. Under these conditions, even at maximum amplification, the PZT ring transducer assisted ulcrafiluration showed an insignificant permeate flux increase of about $5 \%$. 


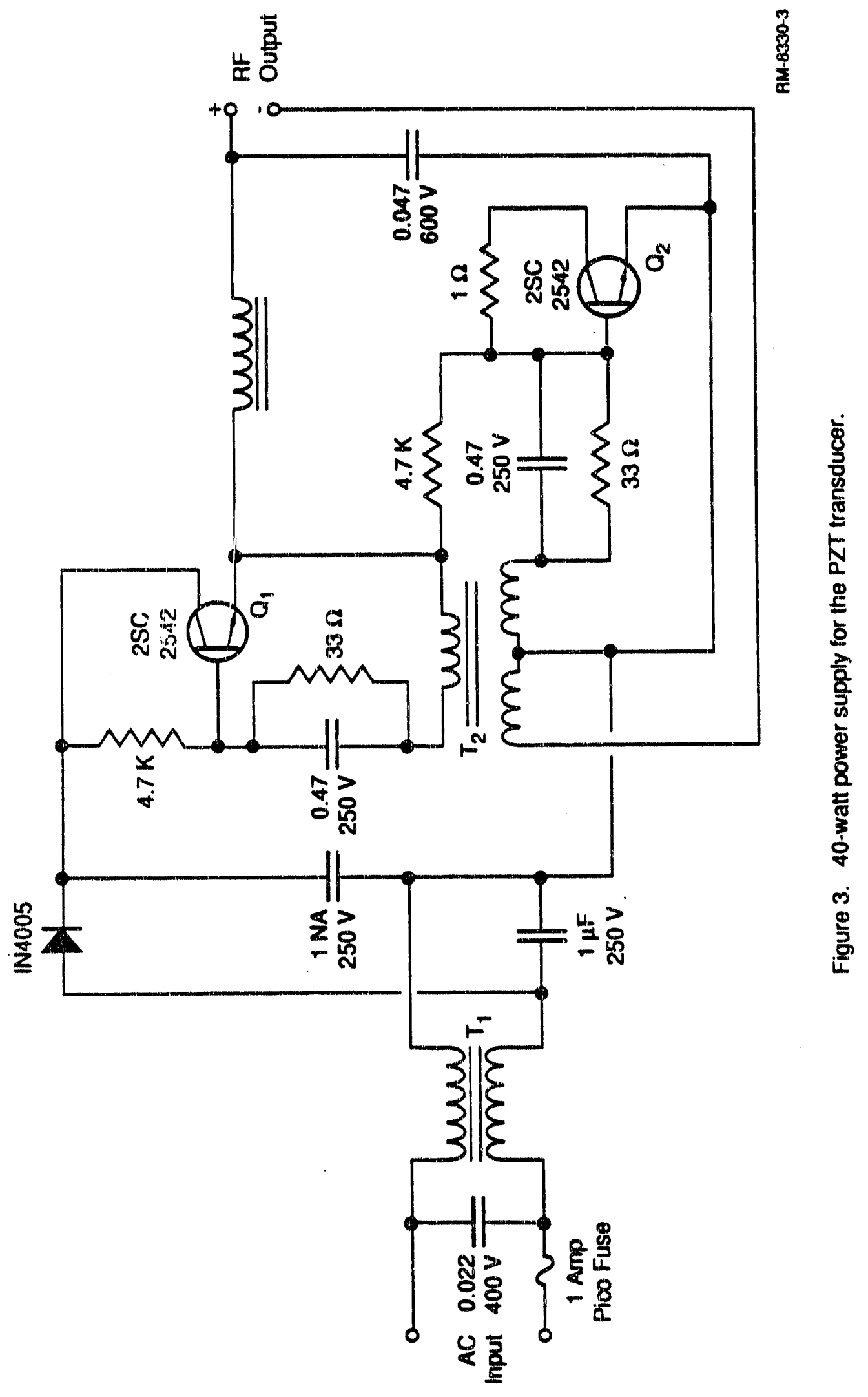




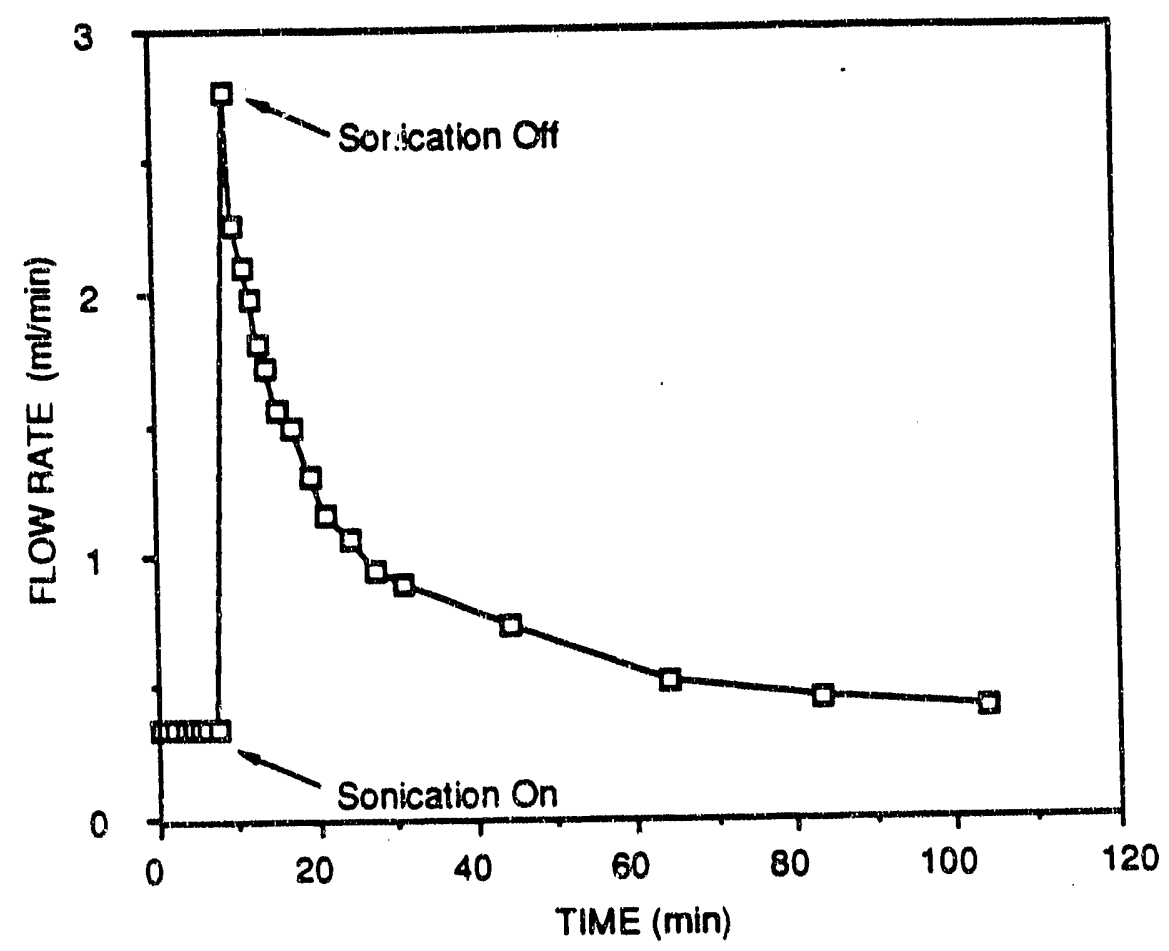

RAM-8330-6

Figure 4. Effect of sonication by a PZT disc transducer on the ultrafiltration flux of a $0.45 \%$ dextran (MW 162,000) solution with a $100,000 \mathrm{MWCO}$ polysulfone membrane. 


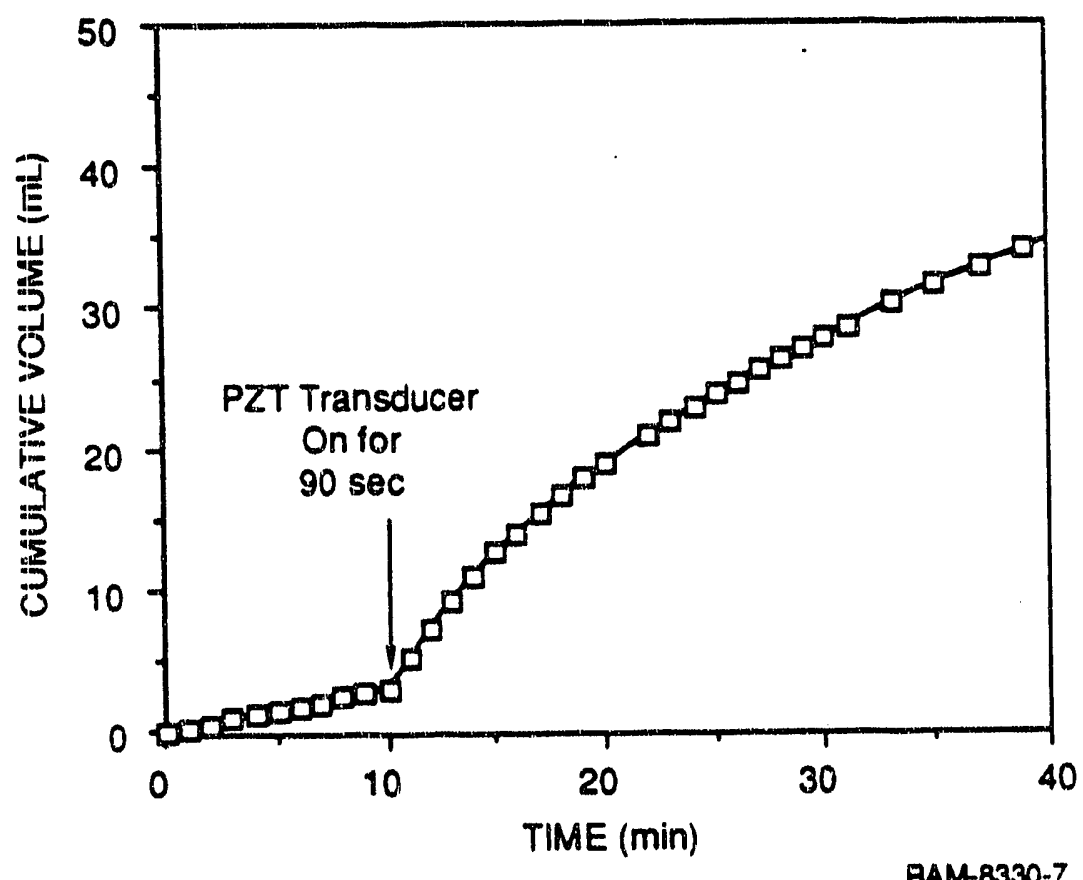

Figure 5. Cumulative permeate volumes of PZT disc-assisted ultrafiltration of a $0.58 \%$ solution of dextran (MW 162,000) with a 100,000 MWCO polysulfone membrane. 
The reproducibility of each of the above illustrated experiments was confirmed by repeated tests. Determinations of the enhancement of permeate flux by piezoelectric disc were conducted several times over a period of one month. The permeate flux was consistently enhanced by a factor of 8 . The piezoelectric disc diameter was $38 \mathrm{~mm}$ and the membranes diameter was $2 \times 76 \mathrm{~mm}$, thus representing area coverage of $12 \%$. We have experimented with area coverage of as low as $5 \%$, although these experiments need to be further examined with appropriate power supplies. While similar experiments are consistent, it is also evident that the absolute permeate flux enhancement is a function of parameters, such as composition and flow rate of the feed solution (as expected). These observations will need to be quantified and correlated during the next phase of this study.

\section{PIEZOELECTRIC HORN-ASSISTED ULTRAFILTRATION}

We used a piezoelectric horn capable of transmitting up to 200 watts of power to a titanium tip at the frequency of $20 \mathrm{KHz}$. The horn was maintained in close contact to the UF membrane, on the permeate side, through a microporous stainless steel filter. The horn was adapted to constitute the top portion of the test cell, as shown in Figure 6. The permeate was therefore collected through an output channel drilled through the horn.

Feasibility tests of the piezoelectric hom assisted ultrafiltration vere carried out on a simplified ultrafiltration apparatus where the whole feed solution was forced through the UF membrane without recirculation of the feed and of the permeate stream. Two experiments, with and without piezoelectric assistance were conducted and compared. A 1\% solution of poly(ethylene glycol) with average molecular weight of 10,000 daltons was prepared and used as feed through a $47 \mathrm{~mm}$. 10,000 MWCO poly(sulfone) UF membrane, mounted on a poiypropylene support. A microporous stainless steel support filter was used to give structural support to the UF membrane. The feed solution was pressurized at 80 psig.

The ultrafiltration test experiments, with and without power applied to the piezoelectric horn, were run independently on the same membrane.

Data were first collected for a filtration experiment of $1 \%$ poly (ethylene glycol) solution without driving the horn. The permeate cumulative volume was plotted at different times (Figure 7, Curve 1). Once the experiment was concluded, the same ultrafiltration membrane was backwashed overnight by circulation of deionized water without opening the flow cell. The flow rate of Milli-Q water was used as a criterion to monitor the proper cleaning of the membrane. 


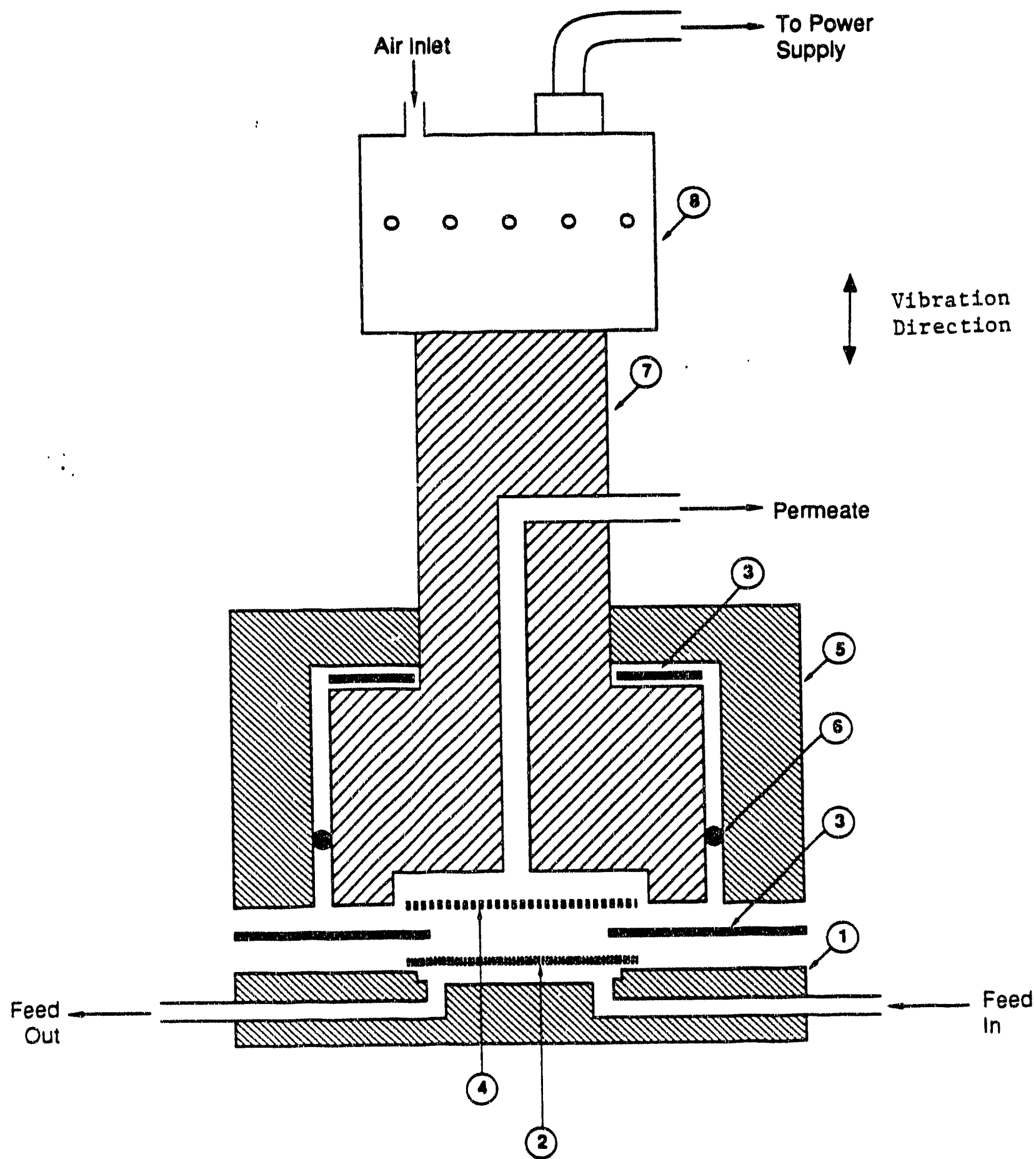
1. Bottom half
5. Top half
2. Ultrafittration membrane
6. O-ring
3. Rubber gasket
7. Thtanium hom
4. Microfitter
8. Piezoelectric element housing

RM-8330-5

Figure 6. Piezoelectric hom-driven ultrafittration test cell. 


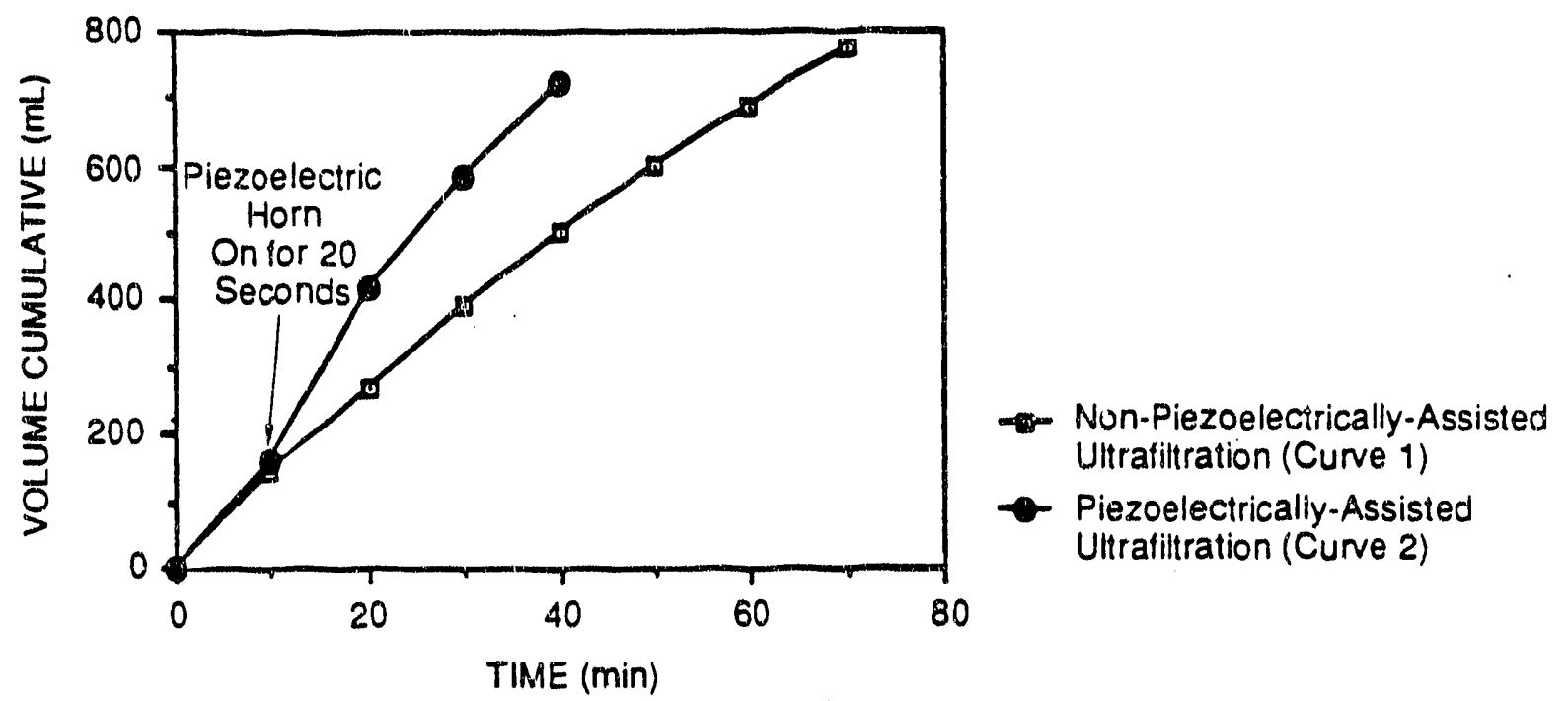

2A-8330-8

Figure 7. Cumulative permeate volumes of the ultrafiltration of a $1 \%$ poly (ethylene giycol) solution.

The piezoelectrically-assisted ultrafiltration was carried out with a piezoelectric hiorn. 
Piezoelectric hom-assisted ultrafiltration of $1 \%$ poly(ethylene glycol) solution was then carried out again on the same membrane. The permeate cumulative volume during the first 10 minutes of the experiment was found to be reproducible and comparable with the previous experiment (Figure 7, Curve 2). The horn was then driven at a nomimal power of 20 watts for twenty seconds. The permeate cumulative volume significantly increased, and was constantly higher for the whole duration of the experiment.

Because of this encouraging result, we went on with the test of piezoelectric horn assisted ultrafiltration in a cross-flow test apparatus. Testing procedures and protocol were established, the most suitable testing conditions were identified, and experimental data on ultrafiltration flux enhancement due to sonication produced by an ultrasonic horn were generated. A summary of the experiments conducted, in chronological order, is shown in Table 1.

To obtain baseline flow rates of the permeate through a fouled membrane, long term tests on the cross-flow filtration apparatus were carried out. Thus, we ran a $0.1 \%$ polyethylene glycol solution with an average molecular weight of 10,000 for 19 days (Experiment \#1). Millipore's low binding regenerated cellulose membranes with a 10,000 MWCO were used for the above experiment. The fouling data show that the cells are subjected to the same inlet conditions and that fouling is qualitatively in accord with the expected behavior (Figure 8).

As described in our original proposal, we had planned on studying a synthetic whey solution. The main component of synthetic whey, besides water, is casein. Therefore a $0.8 \%$ casein solution was mixed in the feed tank (Experiment \#2). However, we could not completely dissolve the casein. We therefore opted for the study of high molecular weight dextran $(162,000$ daltons). Dextran is available in a wide range of molecular weights and is relatively inexpensive.

For the Experiment \#3 we prepared a 1\% dextran solution and we used Millipore's PTHK membranes with molecular weight cut-off of 100,000 . Within thirty-five minutes, the permeate flow rate was no longer measurable. We drove the piezoelectric horn at different nominal powers for one minute each time, and we observed significant increments of the permeate flux that lasted between ten and fifteen seconds. In all cases, we observed a delay of the permeate flux increase from the moment of the sonication start of approximately five seconds. This experiment confirmed previous data registered in a flow-through filtration system.

In the Experiment \#4 we tested a 1\% polyethylene glycol compound solution (MW $15,000-20,000$ ) using a 10,000 MWCO low binding regenerated cellulose membranes. Fouling was observed very quickly. We did not even ty to piezoelectrically drive the hom to enhance flow 
Table 1

SUMMARY OF THE PIEZOELECTRIC HORNASSISTED ULTRAFILTRATION EXPERIMENTS

Feed

Composition (wt\%)

Results/Comments

\begin{tabular}{|c|c|c|c|c|}
\hline No. & Membrane & Solute/Mol Wt. & $(\mathrm{wt} \%)$ & Results/Comments \\
\hline 1 & $\begin{array}{l}\text { Regenerated } \\
\text { cellulose, } \\
10,000 \text { MWCO }\end{array}$ & $\begin{array}{l}\text { Polyethylene } \\
\text { glycol/10,000 }\end{array}$ & 0.1 & $\begin{array}{l}\text { Experiment continued for } 19 \text { days. } \\
\text { Steady decline of flux over time. }\end{array}$ \\
\hline 2 & $\begin{array}{l}\text { Regenerated } \\
\text { cellulose, } \\
10,000 \mathrm{MWCO}\end{array}$ & $\begin{array}{l}\text { Casein/unknown } \\
\text { mol wt }\end{array}$ & 0.8 & $\begin{array}{l}\text { Problems with the dissolution of } \\
\text { solute; system fouling. }\end{array}$ \\
\hline 3 & $\begin{array}{l}\text { Polysulfone, } \\
100,000 \mathrm{MWCO}\end{array}$ & Dextran/162,000 & 1.0 & $\begin{array}{l}\text { Permeate flux became negligible } \\
\text { within } 35 \text { minutes from the start of } \\
\text { the experiment; however, the } \\
\text { vibration of the piezoelestric horn } \\
\text { did improve the flux somewhat }\end{array}$ \\
\hline 4 & $\begin{array}{l}\text { Regenerated } \\
\text { cellulose, } 10,000 \\
\text { MWCO }\end{array}$ & $\begin{array}{l}\text { Polyethylene } \\
\text { glycol compound/ } \\
15,000-20,000\end{array}$ & 1.0 & $\begin{array}{l}\text { Permeate flux became negligible } \\
\text { almost from the beginning }\end{array}$ \\
\hline 5 & $\begin{array}{l}\text { Regenerated } \\
\text { cellulose, } 10,000 \\
\text { MWCO }\end{array}$ & $\begin{array}{l}\text { Polyethylene } \\
\text { glycol compound/ } \\
15,000-20,000\end{array}$ & $2.6^{*}$ & $\begin{array}{l}\text { Reasonably good results. The } \\
\text { vibration of the piezoelectric horn } \\
\text { enhanced the permeate flux } \\
\text { approximately by a factor of } 2\end{array}$ \\
\hline 6 & $\begin{array}{l}\text { Regenerated } \\
\text { cellulose, } 10,000 \\
\text { MWCO }\end{array}$ & $\begin{array}{l}\text { Polyethylene } \\
\text { glycol compound/ } \\
15,000-20,000\end{array}$ & $1.0^{*}$ & $\begin{array}{l}\text { Good results. The vibration of the } \\
\text { piezoelectric hom enhanced the } \\
\text { permeate flux approximately by a } \\
\text { actor of } 4 \text {. Duration of } \\
\text { expermments: } 21 \text { days. }\end{array}$ \\
\hline 7 & $\begin{array}{l}\text { Polysulfone, } \\
100,000 \mathrm{MWCr}\end{array}$ & Dextran/162,000 & $0.1 *$ & $\begin{array}{l}\text { Good results. The vibration of the } \\
\text { p. ezoelectric hom enhanced the } \\
\text { permeate flux approximately by a } \\
\text { factor of } 5 \text {. Duration of } \\
\text { experiments: } 15 \text { days. }\end{array}$ \\
\hline 8 & $\begin{array}{l}\text { Polysulfone, } \\
10,000 \mathrm{MWCO}\end{array}$ & $\begin{array}{l}\text { Polyethylene- } \\
\text { imine } / 50,000- \\
60,000\end{array}$ & 2.5 & $\begin{array}{l}\text { Good results. The vibration of the } \\
\text { piezoelectric horn enhanced the } \\
\text { permeate flux by a factor of } 4 \text {. }\end{array}$ \\
\hline
\end{tabular}

*adjed gradually to feed water 


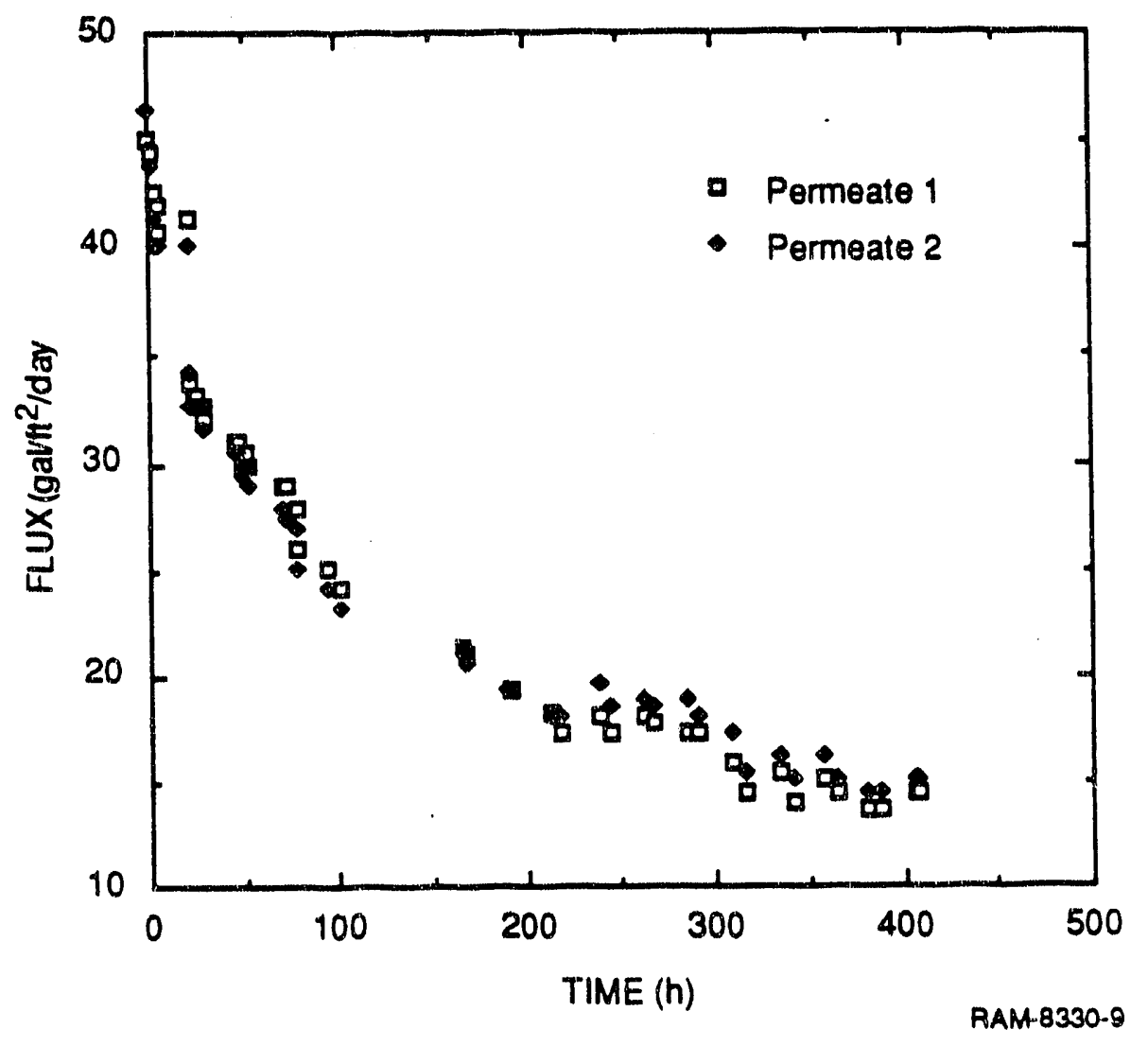

Figure 8. Fouling data for a $0.1 \%$ solution of $10,000 \mathrm{MW}$ polyethylene glycol with 10,000 MWCO regenerated cellulose membranes. 
rates, and instead we cleaned thoroughly the apparatus for another test with a more convenient concentration of poly(ethylene glycol).

By gradually adding polyethylene glycol to the feed solution we had better control of the feed composition, and we could test the ultrafiltration of a $2.6 \%$ poly(ethylene glycol) solution (Experiment \#5). We applied six power pulses to the UF membrane, sixty seconds long, over a period of one hour. The piezoelectrically horn-assisted ultrafiltration enhanced the permeate flux approximately by a factor of 2 .

A more systematic study on the effect of sonication produced by the hom was conducted in the Experiment \# 6. A 1\% polyethyleneglycol solution was studied with a regenerated cellulose UF membrane (MWCO 10,000) and a $0.1 \%$ dextran solution with a polysulfone UF membrane $(100,000 \mathrm{MWCO})$ were studied, respectively. Several sonication pulses were applied during each run. Figure 9 shows the short-term variation of the permeate flux with time for the polyethylene glycol experiments. The upper dotted line represents the flux of pure water through the membrane. Before the piezoelectric horn was driven to enhance ultrafiltration, the membrane was fouled over a period of a few days. The flux thru ugh the fouled membrane is indicated by the lower dotted line. The piezoelectric hom was then periodically driven for about two minutes by applying a formal power of 10 watts. The permeate was substantially enhanced by more than a factor of 4 when the horn was on. Figure 10 shows the long term effece of sonication on long-term performance of the membrane. Initially the feed solution was progressively concentrated to quickly reach steady state fouling conditions. Then the flux was periodically enhanced by driving the piezoelectric hom with 10 watts power ( 2 minutes every 50 hours, on average). The figure compares the flux of the piezoelectrically-driven cell and non-piezoelectrically-driven cells. The permeate flux of the piezollectrically-driven cell is higher than that of the non-piezoelectrically driven cell at the end of 21 days. To examine in detail this effect, we should verify whether any pore size variation of the UF membrane takes place because of vibration. A possible approach would be to inspect the membrane by scanning electron microscopy (SEM) at the end of the sonication test. Such experiments will be carried out during the second year. Our preliminary economic evaluation was calculated on the basis of this particular experiment, because of the availability of long term data. The evaluation (Appendix A) illustrates that PZ-assisted ultrafiltration will make energy saving membrane technology substantially more attractive to industry.

The ultrafiltration of dextran (0.1\%) with molecular weight of 162,000 through polysulfone $100,000 \mathrm{MWCO}$ (Experiment \# 7) showed similar results. The permeate flux was enhanced by approximately a factor of 5 when the hom was piezoelectrically driven. The 


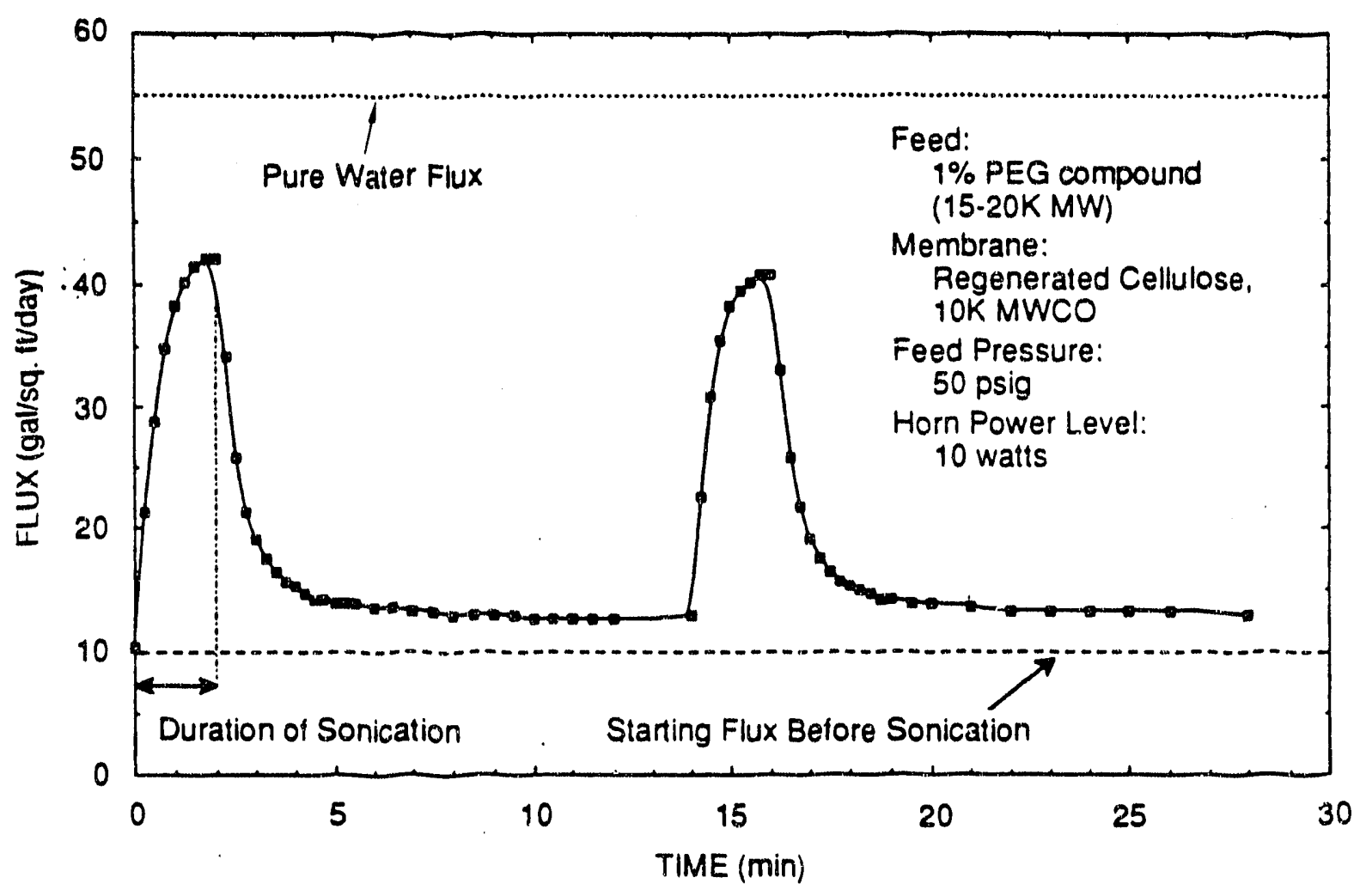

RA-8330-10

Figure 9. Effect of the piezoelectric hom on the uttrafiltration flux of $1.0 \%$ polyethylene glycol solution. 


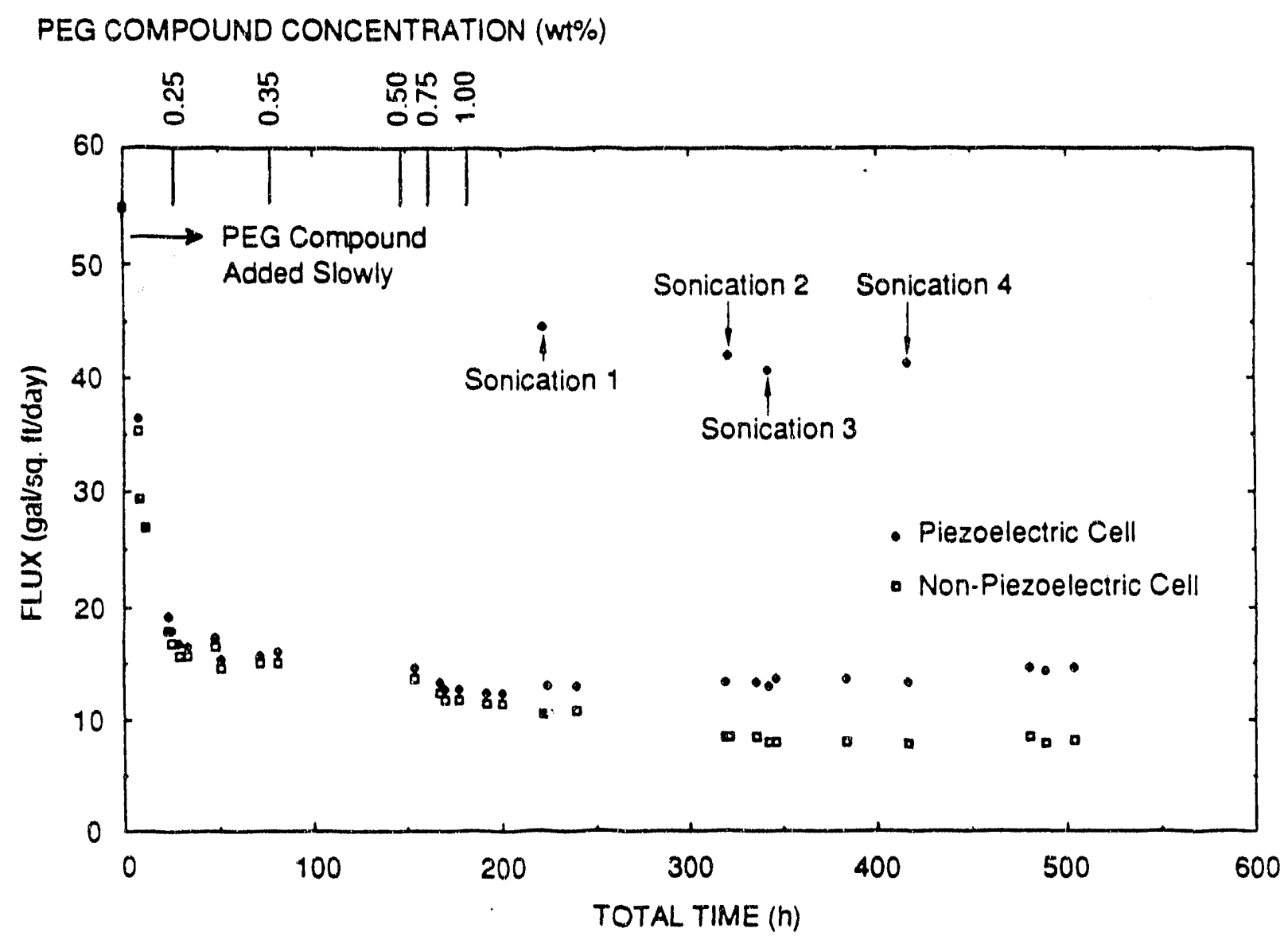

RA.8330.11

Figure 10. Long-term ultrafiltration performance on $1.0 \%$ polyethylene glycol solution. Piezoelectrically-assisted uttrafittration was carried out by a piezoelectric horn. 
ultrafiltration of poly(ethylene imine) (2.5\%), molecular weight 50,000-60,000, through polysulfone 10,000 MWCO also showed good results with a flux enhancement by a factor of 4 .

\section{PVDF FILM ASSISTED ULTRAFILTRATION}

Polyvinylidene fluoride is a well known polymer with piezoelectric properties. As other piezoelectrically active materials, PVDF films can be deformed by selective application of charge to electrically conductive coatings deposited on the opposite sides of the PVDF films. Our objective was to laminate metallized PVDF films, electrically insulated by room temperature vulcanized (RTV) rubber or polyvinylchloride with UF membranes to test their capability to produce local nurbulenre next to the membrane pores therefore reducing the fouling and enhancing the permeate flux.

A. summary of the most representative experiments carried out on PVDF membranes as piezoelectric transducers is illustrated in Table 2.

Since ultrafiltration usually takes place at pressures in the range of 50 to $100 \mathrm{psi}$, we first sought to verify whether, under these conditions the PVDF films vibrate when an external electrical bias is applied. Two metallized PVDF films, separated by a rubber gasket, were compressed at 50 psi. Either one or both the films were coated by a thin film of RTV rubber (Experiments \#1 and 2). One of the films was driven using a function generator, while the other film was connected to an oscilloscope to monitor the vibration of the first membrane. Even if we could not quantify the overall effect, the result of this experiment showed that the piezoelectric effect responsible for the sonication of the PVDF film under external bias takes place also when pressures of about 50 psig are applied. Moreover, we also found that the piezoelectric properties of the piezoelectric film are not significantly affected by the use of the insulating polymer coating.

To use PVDF film as piezoelectric transducer for ultrifiltration, metallized PVDF films bearing holes of about $5 \mathrm{~mm}$ diameters, electrically insulated by a PVC coating were laminated to UF membranes, and preliminarily tested in a flow-through ultrafiltration apparatus. Filtration experiments were conducted with piezoelectric activation (application of a bias to the metallized PVDF film) and without, with a feed solution of polyethyleneglycol in deionized water. As shown in experiments \#3,4 and 5, we did not observe any permeate flux enhancement by using PVDF films either driven by a function generator, or by a pulse generator (higher voltages). The membrane vibration frequency was also varied from $20 \mathrm{KHz}$ to $500 \mathrm{kHz}$ without any positive 
Table 2

\section{SUMMARY OF THE EXPERIMENTS CONDUCTED BY \\ USING PVDF MEMBRANES AS PIEZOELECTRIC TRANSDUCERS}

No.

Description of Experiment

Results/Conclusion

1 Test of a RTV coated PVDF piezoelectric transducer driven by a function generator. An uncoated PVDF film was used to detect the signals generated by the above transducer under a pressure of 50 psig. The sensor and transducer membranes were separated by a rubber gasket.

2 Same as in Expt. \#1 except that the sensor PVDF film is also coated by RTV to assess the effect of dampening

3 Filtration of a $0.5 \%$ solution of poly (vinylpyrrolidone), $40,000 \mathrm{Mw}$, through polysulfone UF membrane, 10,000 MWCO. The PVDF piezoelectric transducer was driven by a function generator.

4 Filtration of a $0.1 \%$ solution of poly (vinylpyrrolidone), $40,000 \mathrm{Mw}$ through polysulfone UF membrane, 10,000 MWCO. The PVDF piezoelectric transducer was driven by a function generator.

5 Filtration of a $0.1 \%$ solution of poly (vinylpyrrolidone), $40,000 \mathrm{Mw}$, through polysulfcne UF membrane, $10,000 \mathrm{MWCO}$ using a glass micro fiber filter as backing. A pulse generator was used to drive the PVDF piezoelectric transducer.

6 Filtration of $0.2 \%$ solution of poly (ethylene glycol), 15,000 Mw through regenerated cellulose UF membrane, $10,000 \mathrm{MWCO}$ using a mylar coated bimorph PVDF piezoelectric transducer.

7 Filtration of a solution of $0.5 \%$ poly (ethylene glycol), $10,000 \mathrm{Mw}$, through regenerated cellulose UF membrane, 10,000 MWCO assisted by a polymorph PVDF piezoelectric transducer driven by a pulse generator.

No enhancement of permeate flux was observed.

No enhancement of permeate flux was observed.

No enhancement of permeate flux was observed.

No enhancement of permeate flux was observed.

No enhancement of permeate flux was observed.

Vibration signals are detected by the RT / coated PVDF reduction of piezoelectric properties due to the RTV coating.

The RTV coated PVDF piezoelectric transducer is not signals are detected by the sensor PVDF film. fux was observed. 
result. Because of the weak mechanical properties of PVDF, we believe that the electromechanical conversion is insufficient to enhance the permeate flux during ultrafiltration.

In the attempt to overcome this drawback bimorph and polymorph membranes were used. The polymorph PVDF films consisted of four PVDF perforated films, joined to each other by conducting silver ink. Leads connected to different constituent membranes were joined so that the surfaces of PVDF films joined together by silver ink had the same polarity as shown in Figure 11. The polymorph film was encapsulated in a thin coating of RTV. The bimorph was similarly made of two PVDF films.

However, the results of ultrafiltration tests with polymorph PVDF films were not encouraging either (Experiments \# 6 and 7 ). 


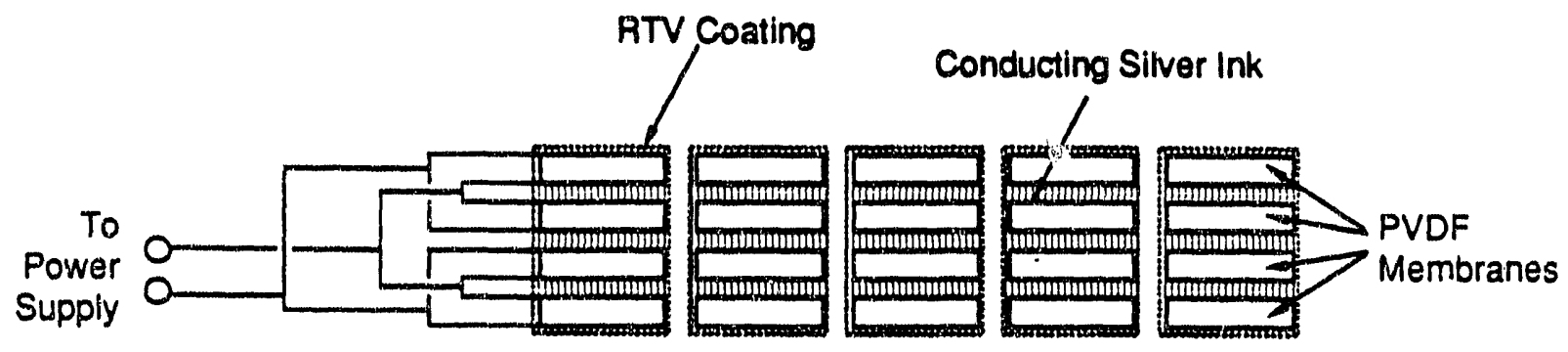

(a) Cross Section

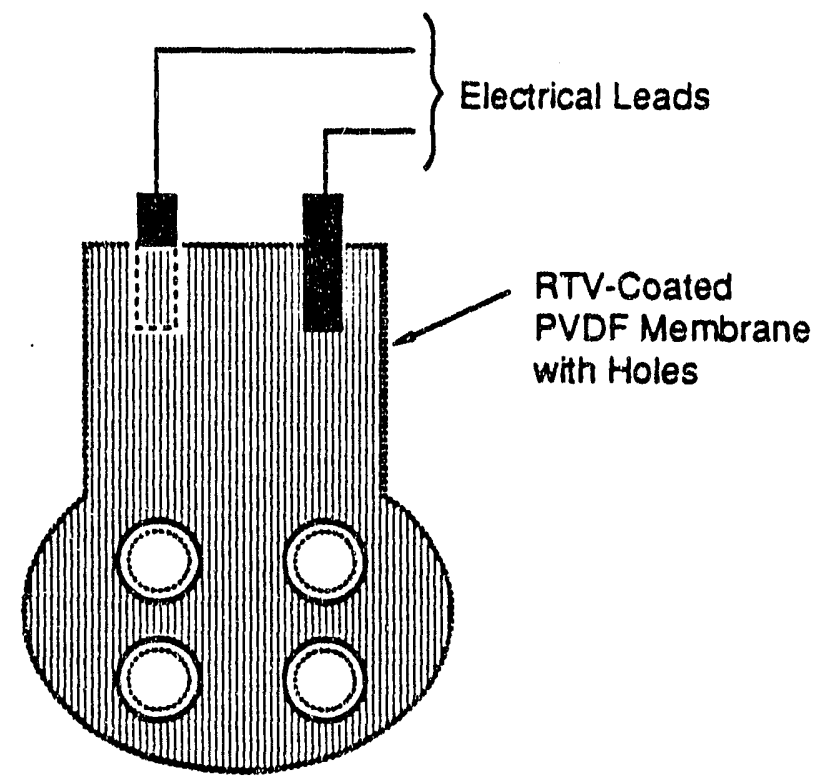

(b) Top View

$R M \cdot 8330 \cdot 12$

Figure 11. Schematic representation of the PVDF polymorph membrane with holes. 


\section{FURTHER DEVELOPMENT}

We have demonstrated the feasibility of piezoelectrically assisted ultrafiltration as a cost effective means to reduce fouling and enhance the flux through ultrafiltration membranes. PZT discs are very effective piezoelectric drivers that presumably promote local turbulence next to UF membranes. Because of their small size and ease of adaptability to ultrafiltration apparatus, PZT transducers may be feasible for use in spiral wound membrane modules.

In our future work we will continue the development of laminated membranes fabricated from commercially available UF membranes and piezoelectric materials. We will seek to develo: a second generation of piezoelectric drivers for ultrafiltration based on porous piezoelectric ceramic microfilters. The piezoelectric elements will be studied to optimize their vibration amplitude and frequency. Tests at different frequencies will be carried out by changing the size of the piezoelectric element to assess the effect of frequency on the permeate flux enhancernent. Although preliminary experiments can be carried out by driving the piezoelectric elements off resonance, such experiments lead to excessive heat generation and inefficient use of power. Ultimately, the experiments will have to be carried out by changing the disc size.

Detailed long term flat sheet ultrafiltration experiments with the newly developed piezoelectric membranes, both laminated and porous, will be carried out. We will characterize the permeation behavior of prototypical piezoelectric driver configurations with a range of flows, and with different UF membranes. Continuous and pulse piezoelectrically enhanced ultrafiltrations will be conducted and compared on model feed solutions, such poly (ethylene glycol) and dextran w'th polysulfone and regenerated cellulose. We will also configure the piezoelectric elements in a manner prototypical of that required for incorporation into a spiral module.

Economic evaluations will be also carried out to calculate the process economics for piezoelectrically assisted ultrafiltration of whey protein and oil/solvent mixtures in deasphalting operations. 
Appendix

ECONOMIC EVALUATION OF SOLVENT RECOVERY

IN DEASPHALTING OPERATIONS WITH PIEZOELECTRICALLY ENHANCED ULTRAFILTRATION MEMBRANES 


\section{ECONOMIC EVALUATION OF SOLVENT RECOVERY IN DEASPHALTING OPERATIONS WITH PIEZOELECTRICALLY ENHANCED ULTRAFILTRATION MEMBRANES}

To assess the economic viability of our piezoelectric (PZ) technology, we have considered the recovery of solvent from an oil deasphalting operation. We mentioned this application in our original proposal as one offering good potential for national energy savings. Much of our information on this process will be drawn from a report recently submitted to EG\&G-Idaho (Gottschlich and Roberts, 1990).

Deasphalting of oil is a widely-practiced process in refining. In traditional deasphalting, solvent recovery is done by evaporating the solvent (Figure A-1). The energy consumed in the evaporation exceeds $1000 \mathrm{Btu} / \mathrm{lb}$ of deasphalted oil (DAO; thermal energy equivalent; Table A-1). The capital investment for this facility is $\$ 4.3$ million (Table A-2). The "discounted cash flow" cost of deasphalting oil by this process is 1 cent/lb of deasphalted oil (DAO; Table A-3).

Ultrafiltration (UF) membranes, in principal, can recover the solvent without a phase change, thereby saving substantial energy (Figure A-2). Membranes are not feasible to perform the complete separation, and some assistance by conventional evaporation is required. The energy consumed by this "hybrid" process is $449 \mathrm{Bru} / \mathrm{lb}$ of DAO (Table A-4), a savings of $924 \mathrm{Btu} / \mathrm{lb}$ of DAO. If this savings were realized by the commercial sector, the national energy savings would be 28 trillion Btu/yr (based on 1985 deasphalting capacity in U.S. of 283,000 barrels/day).

The installation of a membrane unit is, however, rather capital intensive, and the total required capital cost of this process is nearly double that of the traditional process (Table A.5). As a consequence, the total processing cost decreases to only 0.876 cents/1b DAO (Table A-6). This rather minor decrease in the cost versus the traditional process is probably not enough to convince 


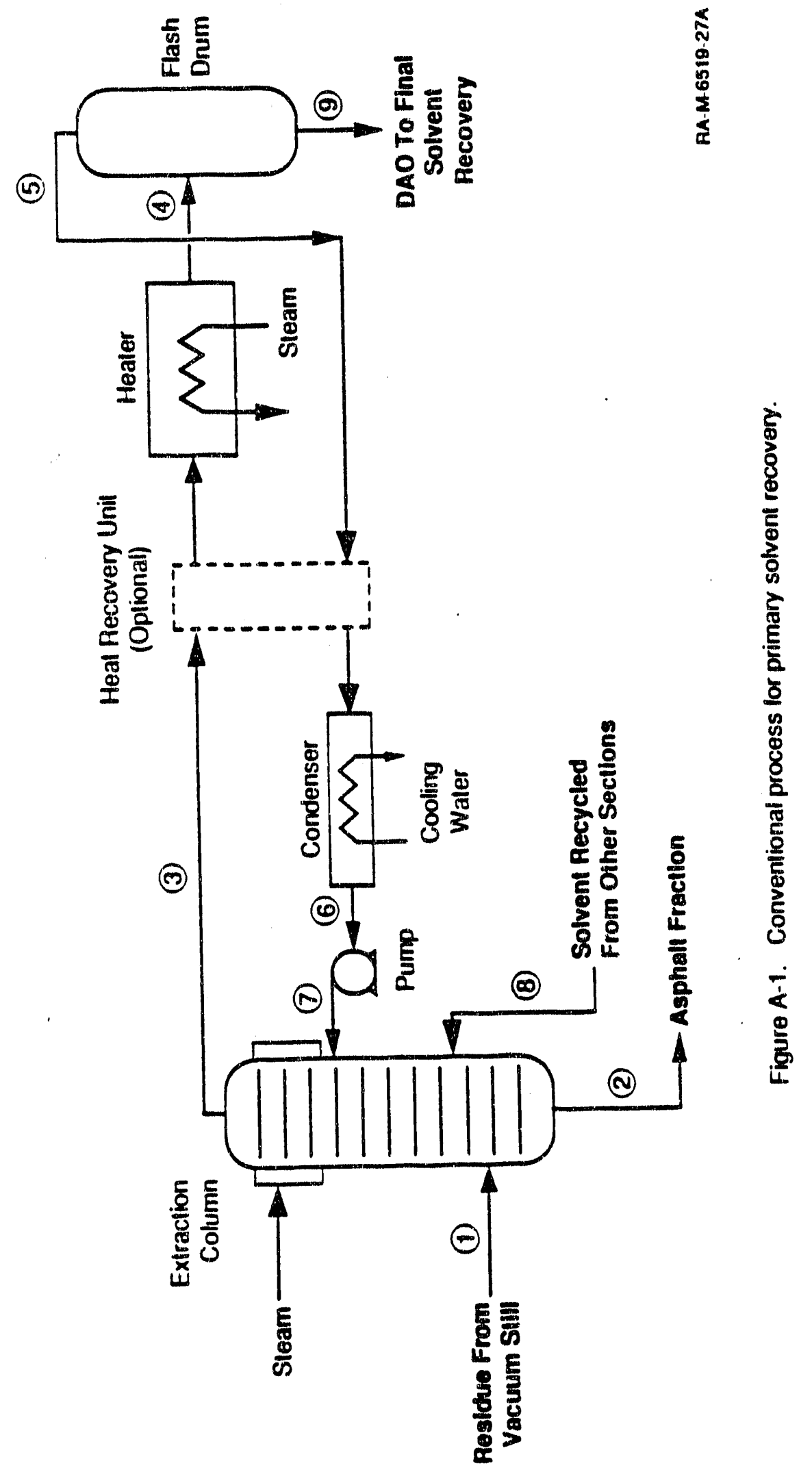

$A-3$ 
Table A-1
UTILITY REQUIREMENTS FOR SOLVENT RECOVERY IN SOLVENT DEASPHALTING WITH EVAPORATION TECHNOLOGY ALONE
(Basls: 95\% DAO, 100,000 ib DAO/hr)

\begin{tabular}{|c|c|c|c|c|c|}
\hline & \multicolumn{5}{|c|}{ Utillity } \\
\hline & \multicolumn{2}{|c|}{ Sieam } & \multirow[b]{2}{*}{ Water } & \multirow[b]{2}{*}{ Electrialty } & \multirow[b]{2}{*}{ Iotal } \\
\hline & $\begin{array}{l}\text { Extractlon } \\
\text { Tower }\end{array}$ & $\begin{array}{c}\text { Evap } \\
\text { Heater }\end{array}$ & & & \\
\hline $\begin{array}{l}\text { Mass flow } \\
(\text { bo/b DAO) }\end{array}$ & 0.18 & 1.20 & 43.5 & $\cdots$ & $\cdots$ \\
\hline $\begin{array}{l}\text { Energy flow } \\
(\text { Btu/b DAO) }\end{array}$ & 150 & 991 & $-1,085$ & 9.91 & $\cdots$ \\
\hline $\begin{array}{l}\text { Thermal energy } \\
\text { equivalent" } \\
\text { (Btu/lb DAO) }\end{array}$ & 177 & 1,166 & $\cdots$ & 29.7 & 1,373 \\
\hline
\end{tabular}

Source: Gottschlich and Roberts (1990).

- Thermal energy equivalents are based on an electric power generation efficiency of $33 \%$ and a steam generation efficiency of $85 \%$.

Table A-2

CAPITAL INVESTMENT FOR SOLVENT RECOVERY IN SOLVENT DEASPHALTING WITH EVAPORATION TECHNOLOGY ALONE

(Basis: 95\% DAO, 100,000 lb DAO/hr)

\begin{tabular}{lr}
\multicolumn{1}{c}{ Process Unlt } & $\begin{array}{c}\text { Installed Cost } \\
(\$ 1.000)\end{array}$ \\
\cline { 2 - 2 } Extraction tower & $\$ 1,410$ \\
Process heater & 414 \\
Flash drum & 736 \\
Condenser & 1,084 \\
Evaporation pump & 122 \\
General services & 565 \\
TOTAL & $\$ 4,332$ \\
\hline Source: Gottschlich and Foberts (1990).
\end{tabular}




\section{Table A-3 \\ SOLVENT DEASPHALTING WITH EVAPORATION TECHNOLOGY: \\ ESTIMATED ANNUAL OPERATING COSTS AND PROCESSING COST \\ (Basis: 95\% DAO, 100,000 ib DAO/hr)}

Maintenance materlais

Labor

Operating labor

Supervision

Maintenance labor

Benefits

Total labor

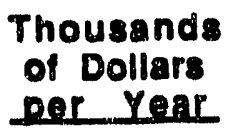

$\$ \quad 87$

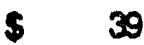

22

108

6.0

$\$ 220$

$\$ 5,460$

115

234

Electric power

Cooling water

Total utilities

0.691

0.015

0.030

68.9

1.5

3.0

Fixed costs

Corporate costs

General administrative expenses

Property taxes and insurance

Total fixed costs

Total annual operating costs

Capital-related charges and income tax

Total processing cost

5,808

73.3

\$ 159

34

234

0.736

0.020

0.004

0.014

2.0

0.4

14

$5 \quad 301$

0.038

3.8

\$ 6,425

0.814

81.0

$\$ 1.503$

0.190

190

\$ 7,928

1.004

100.0 


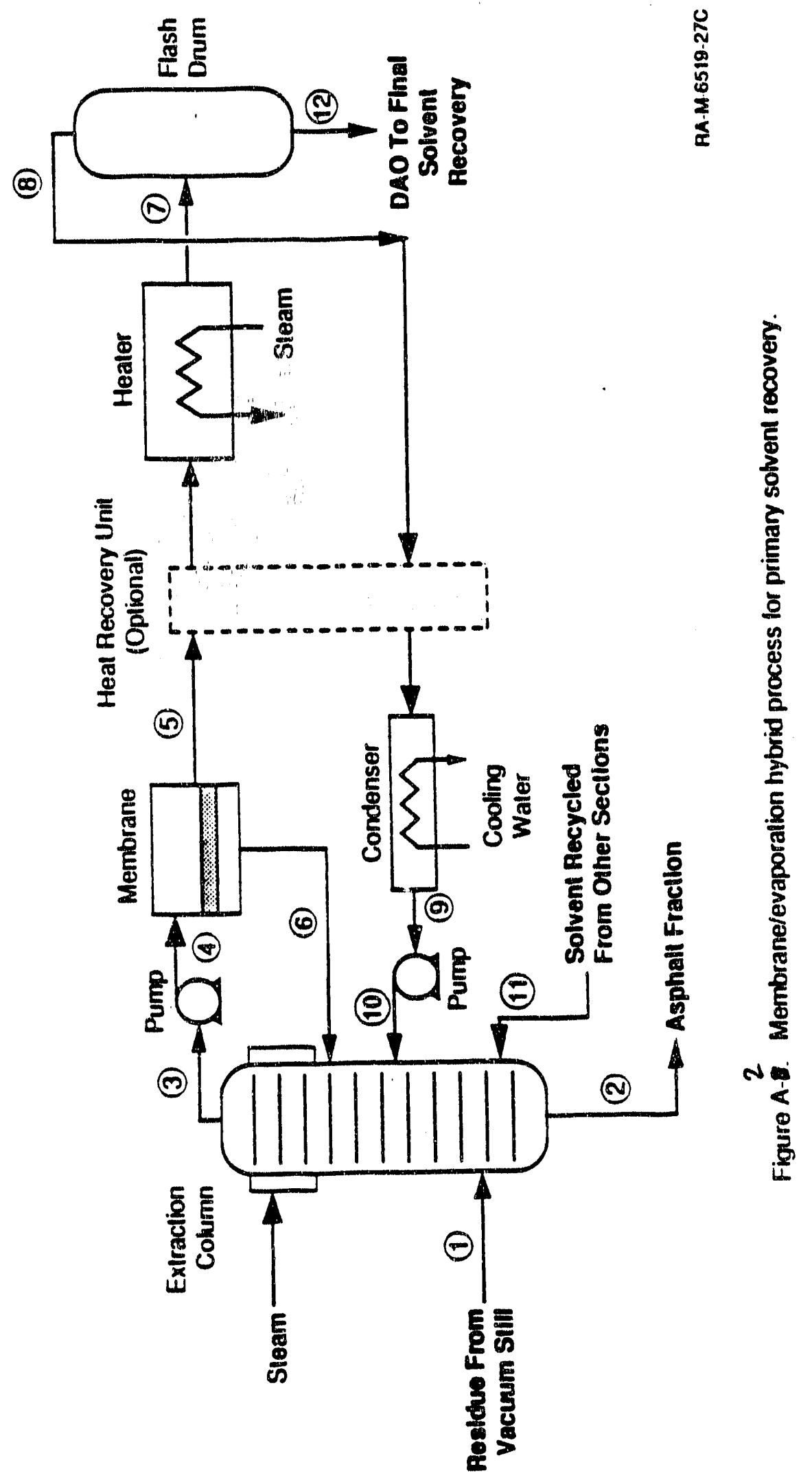

A-6 
Table A-4

UTILITY REQUIREMENTS FOR SOLVENT RECOVERY IN SOLVENT DEASPHALTING WITH MEMBRANE/EVAPORATION HYBRID TECHNOLOGY

(Basls: im $=0.5 ; 95 \%$ DAO; 100,000 ib DAO/hr)

villity

\begin{tabular}{|c|c|c|c|c|}
\hline \multicolumn{2}{|c|}{ Sieam } & & \multicolumn{2}{|c|}{ Electriclty } \\
\hline $\begin{array}{c}\text { Extractlon } \\
\text { Tower }\end{array}$ & $\begin{array}{l}\text { Evap } \\
\text { Heater }\end{array}$ & Water & $\begin{array}{l}\text { Memb } \\
\text { Pumb }\end{array}$ & $\begin{array}{l}\text { Evap } \\
\text { Pump }\end{array}$ \\
\hline
\end{tabular}

\begin{tabular}{ccccccc}
$\begin{array}{c}\text { Mass flow } \\
\text { (b/b DAO) }\end{array}$ & 0.044 & 0.337 & 11.2 & $\ldots$ & $\ldots$ & $\ldots$ \\
$\begin{array}{c}\text { Energy flow } \\
(\text { Btu/b DAO) }\end{array}$ & 36.4 & 278 & -279 & 23.6 & 2.86 & $\ldots$ \\
$\begin{array}{c}\text { Thermal energy } \\
\text { equivalent } \\
\text { (Btu/lb DAO) }\end{array}$ & 42.8 & 327 & $\ldots$ & 70.8 & 8.58 & 449 \\
\hline
\end{tabular}

Source: Gottschlich and Roberts (1990).

Table A-5

CAPITAL INVESTMENT FOR SOLVENT RECOVERY IN SOLVENT DEASPHALTING WITH

MEMBRANE/EVAPORATION HYBRID TECHNOLOGY

(Basls: $\phi \mathrm{m}=0.5,95 \%$ DAO; 100,000 lb DAO/hr)

\begin{tabular}{lr} 
Process Unlt & $\begin{array}{r}\text { installed Cost } \\
(\$ 1.000)\end{array}$ \\
\hline Membrane unit' & $\$ 3,863$ \\
Membrane pump & 296 \\
Extraction tower & 2,035 \\
Process heater & 146 \\
Flash drum & 591 \\
Condenser & 344 \\
Evaporation pump & 38 \\
General services & 1.097 \\
TOTAL & $\$ 8,409$ \\
\hline
\end{tabular}

Source: Gottschlich and Roberts (1990).

- Membrane replacement $=\$ 1,610,000$ 
Tabie A-6

SOLVENT DEASPHALTING WIYM MEMBRANE/EVAPORATION HYBRID TECHNOLOGY: ESTIMATED ARSHAL OPERATING COSTS AND REVENUE AEQUIREMENTS

(Basis: $\phi_{m}=0.5 ; 95 \%$ DAO, 100,000 ibs DAO/hr)

Thousands of Dollars Der Year.

Malntenance materials

Labor

Operating labor

Supervision

Maincenance labor

Benefits

Total labor

\$ 168

$\$ 39$

37

210

101

$\$ 388$
$\$ 1,504$

Cooling water
Electric power

Total utilities

Steam
\$ 1,871

\section{Cents per}

Pound

of DAO

0.021

0.005

0.005

0.027

0.013

0.049
5.6

Percent

of Total

12.4

0.6

0.5

3.0

15

UtIlitles

0.190

0.039

0.008

21.8

4.4

0.9

27.1

Fixed costs

Corporate costs

General administrative expenses

Property taxes and insurance

$\$ 138$

57

210

Total fixed costs

Total annual operating costs

Capital-related charges and income tax

Total processing cost

0.237

0.020

0.007

0.027

0.051

0.359

0.517

0.876
2.0

0.8

3.0

5.9

41.0

590

100.0

Source: Gottschlich and Poberts (1990). 
industry to switch technologies. Keller (1990) has observed that industry rarely spends capital to conserve energy and often spends energy if it saves on capital. Therefore, to realize the substantial energy savings potential of ultrafiltration, a lower capital cost for the membrane system would be highly desirable.

Our PZ membrane system lowers the capital cost of using membranes. It does so because it maintains a higher flux than in a conventional membrane, and we therefore need less membrane to get a given job done. The capital cost per unit area of our $\mathrm{PZ}$ membrane will likely exceed that of a conventional membrane. We have sought consultation with an industrial membrane supplier (Koch Membrane Systems) on the issue of capital cost. Dr. Jamie Monet, director of research at Koch Membrane Systems, advised us that our raw materials cost would be typically a $20 \%$ increase in today's raw material cost. In addition, he advised us that unless we make our driver film thinner, we will get $25 \%$ less membrane area in a module housing. Raw materials cost is only a portion of the overall module cost, so a $20 \%$ raw materials cost increase does not increase the module cost by $20 \%$. However, Dr. Monet felt that overall, there would be a $50 \%$ cost increase for a complete UF system. We will use this $50 \%$ figure in our economic analysis. In addition, we have done our analysis with a factor of $2(100 \%)$ capital cost increase to assess a worst case scenario.

Our PZ driver consumes energy, and therefore, the energy consumption with our PZ membranes exceeds that for a conventional membrane." We take our energy consumption to be the same per unit of DAO as in our annual report dated November 1990. This assumptior. over estimates the power consumption because an alternative logical assumption is to take the power per

\footnotetext{
- Another option for taking advantage of the PZ membrane is to reduce the pump feed pressure so that the same flux is achieved as with a conventional membrane. This approach saves energy, but the energy consumed by the UF feed pump is so trivial compared with the solvent evaporator that it is of no economic consequence to reduce the feed pump pressure.
} 
unit of membrane area the same as in our annual repor. However, the energy consumption is so small that our over estimation does not materially influence our analysis and is appropriate given the need to address quickly DOE's questions about the economic attractiveness of this process.

We take our flux enhancernent to be a factor of 8 because this increase has been observed with our PZT disks (Pg. 9 of annual report). With these factors, the energy consumption of the PZ membrane hybrid system rises slightly to 463 Btu/b (Table A-7), and even with a 50\% capital cost increase for our PZ membrane system, the total system capital cost decreases substantially to \$4,800 (Table, A-8). The total processing cost now drops to 0.574 cents/b of DAO (Table A-9). We have done similar calculations for the factor of 2 (worst case) capital cost increase scenario, as noted in Table A-10.

The PZ membrane process is the most economical of all three processes whether the membrane capizal cost increase is $50 \%$ or even $100 \%$ (factor of 2; Table A-10). Significandly, the capital cost of the entire process with our PZ membrane is only $11 \%$ to $17 \%$ above a process with no membranes as all. Further, the processing cost with respect to traditional technology is $40 \%$ to $50 \%$ less, a strong commercial incentive. Therefore, the $\mathrm{PZ}$ membrane makes it much more likely that industry will adopt energy-saving membrane tech.nology. In this one application, the energy saving potential is about $910 \mathrm{Bru} / \mathrm{b}$ DAO or 27 trillion Bra/yr nationwide. The electricity consumed by the piezoelectric portion of the PZ membrant: comes to $4.7 \mathrm{Btu}$ of electricity/b of DAO $\left(1.377 \cdot 10^{-3} \mathrm{kWh} / \mathrm{b} b\right)$. At an electricity cost of $5 \notin / \mathrm{kWh}$, the additional electricity cost of running the $\mathrm{PZ}$ membrane adds $\$ 6.9 \cdot 10^{-5} / \mathrm{bb}$ of $\mathrm{DAO}$. This figure is completely insignificant which is why (at least in this case) the best way to use the $P Z$ membrane is to reduce the required membrane capital cost so that the intrinsic energy saving potential of ultrafiltration is commercially attractive. 
Table A-7

UTILITY REQUIREMENTS FOR SOLVENT DEASPHALTING

WITH PIEZOELECTRIC MEMBRANE HYBRID TECHNOLOGY

(Basls: $\phi m=0.5 ; 95 \%$ DAO; 100,000 lb DAO/hr)

Utilitity

\begin{tabular}{|c|c|c|c|c|c|c|c|}
\hline & Ste: & & & & Elestrle & & \\
\hline & $\begin{array}{l}\text { Extractlon } \\
\text { Tower } \\
\end{array}$ & $\begin{array}{c}\text { Evap } \\
\text { Heater }\end{array}$ & Water & $\begin{array}{l}\text { Memb } \\
\text { Dump }\end{array}$ & $\begin{array}{c}\text { Pz } \\
\text { prlver }\end{array}$ & $\begin{array}{l}\text { Evap } \\
\text { Eump }\end{array}$ & Iotal \\
\hline $\begin{array}{l}\text { Mass flow } \\
\text { (b/b DAO) }\end{array}$ & 0.044 & 0.337 & 11.2 & $\cdots$ & $\cdots$ & $\cdots$ & $\cdots$ \\
\hline $\begin{array}{l}\text { Energy flow } \\
\text { (Btunb DAO) }\end{array}$ & 36.4 & 278 & -279 & 23.6 & 4.7 & 2.86 & $\cdots$ \\
\hline $\begin{array}{l}\text { Thermal energy } \\
\text { equivalent } \\
\text { (Btu/lb DAO) }\end{array}$ & 42.8 & 327 & ... & 70.8 & 14.1 & 8.58 & 463 \\
\hline
\end{tabular}

Table A-8

CAPITAL INVESTMENT FOR SOLVENT DEASPHALTING WITH PIEZOELECTRIC MEMBRANE HYBRID TECHNOLOGY WITH 50\% MEMBRANE CAPITAL COST INCREASE

(Basls: $\phi m=0.5,85 \%$ DAO; $100,000 \mathrm{lb} \mathrm{DAO} / \mathrm{hr}$ )

\begin{tabular}{lr} 
Process Unit & $\begin{array}{r}\text { Installed Cost } \\
(\$ 1.000)\end{array}$ \\
\cline { 2 - 2 } Membrane unit* & $\$ 724$ \\
Membrane pump & 296 \\
Extraction tower & 2,035 \\
Process heater & 146 \\
Flash drum & 591 \\
Condenser & 344 \\
Evaporation pump & 38 \\
General services & 526 \\
TOTAL & $\$ 4,800$ \\
\hline
\end{tabular}

- Membrane replacement $=\$ 302,000$ 
Table A.9

SOLVENT DEASPHALTING WITH PIEZOELECTRIC MEMBRANE HYBRID TECHNOLOGY: ESTIMATED ANNUAL OPERATING COSTS AND REVENUE REQUIREMENTS WITH 50\% MEMBRANE CAPITAL COST INCREASE

(Basls: $\phi_{m}=0.5 ; 95 \%$ DAO, 100,000 lbs DAO/hr)

Malntenance materlals

Labor

Operating labor

Supervision

Maintenance labor

Benefits

Total labor

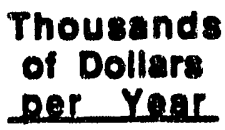

$\$ 96$

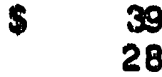

28

120

5

s 250

Conts per
Pound
of DAO

0.012

0.005

0.004

0.015

0.008

0.032

0.190

0.046

0.008

0.244

s 1,925

Electric power

Total utilities

Flxed costs

Corporate costs

General administrative expenses

Propenty taxes and insurance

Total fixed costs

Total annual operating costs

Capital-related charges and income tax

Total processing cost

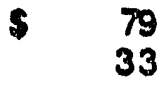

120

5

0.010

0.004

0.015

1.7

0.7

27

0.029

0.317

0.257

0.574

$\$ 2,502$

5.1

$\$ 2026$

447

$\$ 4,528$

100.0
Percent of rotal

2.1

0.9

0.6

2.7

14

5.5

33.2

8.0

13

42.5 
Table A.10

COMPARISON OF THREE PROCESSES FOR SOLVENT RECOVERY IN

DEASPHALTING OPERATIONS

Process

\begin{tabular}{|c|c|c|c|c|}
\hline & \multicolumn{4}{|c|}{ Procers } \\
\hline & \multirow[b]{2}{*}{ Iroditlonal } & \multirow[b]{2}{*}{$\begin{array}{c}\text { Conventional } \\
\text { Membrane Hyorld }\end{array}$} & \multicolumn{2}{|c|}{$\begin{array}{l}\text { Pz Membrane Hybrid } \\
\text { with Membrane } \\
\text { Capltal Cost Increase }\end{array}$} \\
\hline & & & $50 \%$ & $100 \%$ \\
\hline Energy (Btu/lb DAO) & 1,373 & 449 & 463 & 463 \\
\hline Capital Cost (ihousands of \$) & 4,332 & 8,409 & 4,800 & 5,078 \\
\hline $\begin{array}{l}\text { Overall Processing Cost } \\
\text { (屯/D DAO) }\end{array}$ & 1.004 & 0.876 & 0.574 & 0.593 \\
\hline
\end{tabular}




\section{REFERENCES}

Keller, G., "Research for Industrial Separations," U.S. DOE Workshop on Advances in Industrial Separations Technologies, March 1990, Orlando, FL.

Gottschlich, D. E., and D. L. Roberts, "Energy Minimization of Separation Processes Using Conventional/Membrane Hybrid Systems," Final Report to EG\&G-Idaho, Subcontract C88101848, September 28, 1990. 

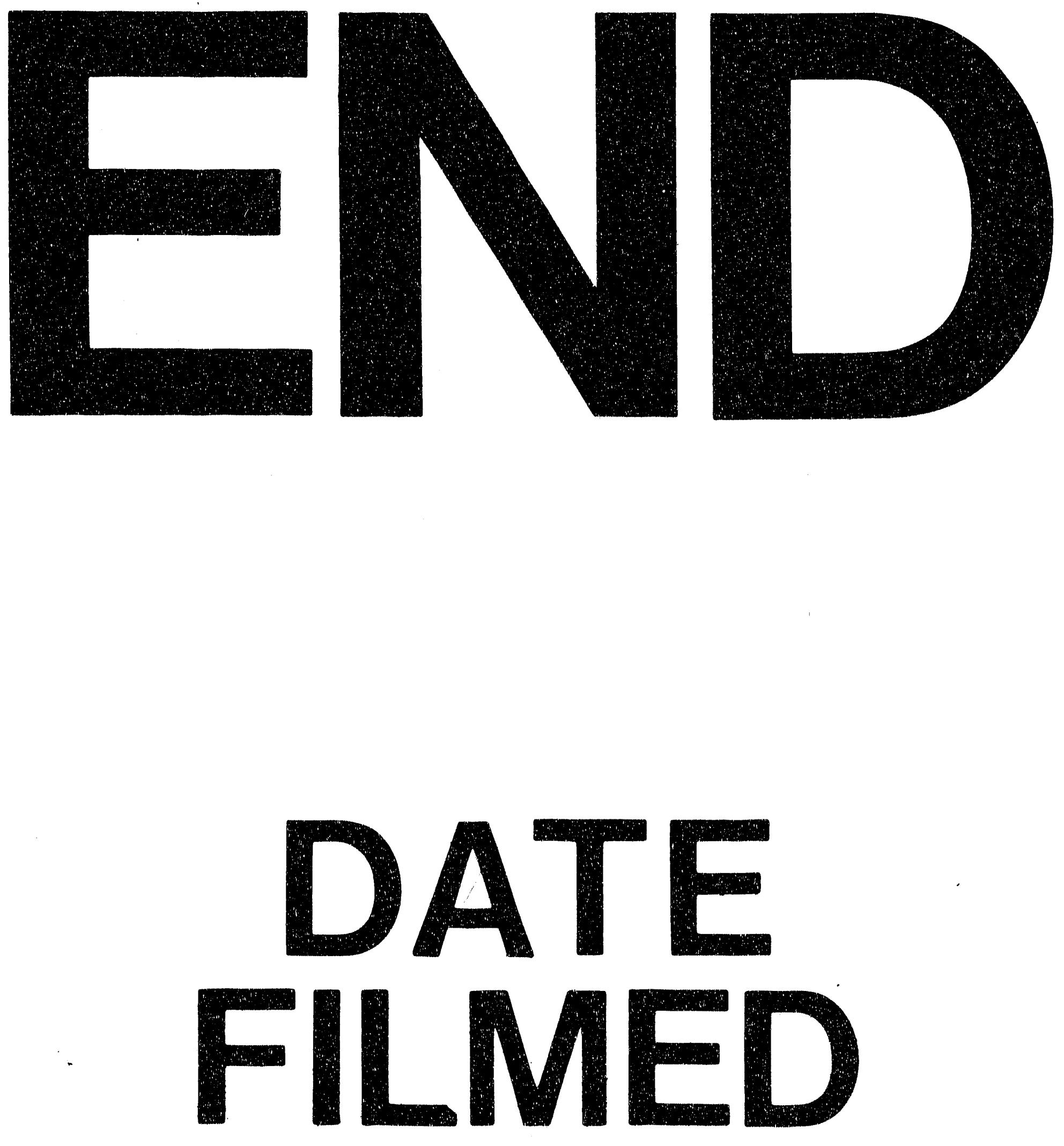

1

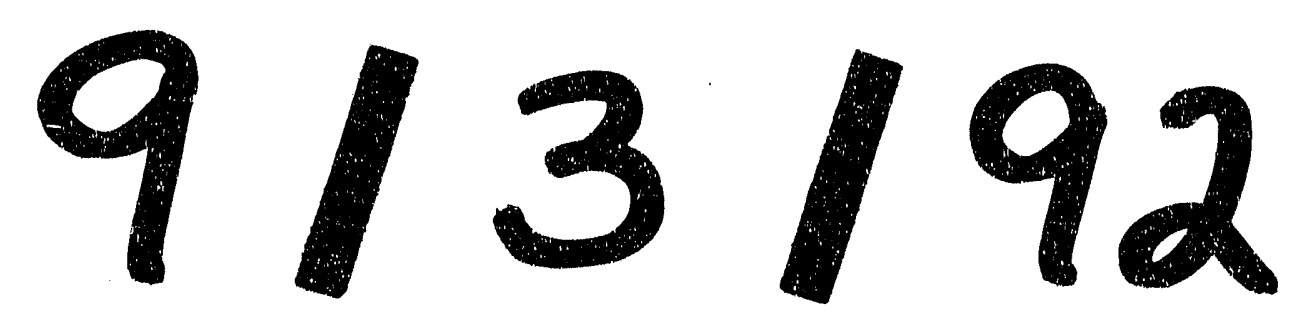


" $\quad$ " $\quad$ " " " " " 